\title{
ASSESSMENT OF IMPACTS AT THE ADVANCED TEST REACTOR AS A RESULT OF CHEMICAL RELEASES AT THE IDAHO CHEMICAL PROCESSING PLANT
}

\author{
Arthur S. Rood
}

\author{
EGG-EST--9523 \\ DE93 005270
}

Published February 1991
Idaho National Engineering Laboratory EG\&G Idaho Inc. Idaho Falls Idaho 83415

\section{U.S. Department of Energy} Idaho Operations office DOE Contract Number DE-AC07-76ID01570

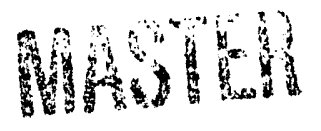




\section{ABSTRACT}

This report provides an assessment of potential impacts at the Advanced Test Reactor Facility (ATR) resulting from accidental chemical spill at the Idaho Chemical Processing Plant (ICPP). Spills postulated to occur at the Lincoln Blvd turnoff to ICPP were also evaluated. Peak and time weighted average concentrations were calculated for receptors at the ATR facility and the Test Reactor Area guard station at a height above ground level of $1.0 \mathrm{~m}$. Calculated concentrations were then compared to the 15 minute averaged Threshold Limit Value - Short Term Exposure Limit (TLV-STEL) and the 30 minute averaged Immediately Dangerous to Life and Health (IDLH) limit. Several different methodologies were used to estimate source strength and dispersion.

Fifteen minute time weighted averaged concentrations of hydrofluoric acid and anhydrous ammonia exceeded TLV-STEL values for the cases considered. The IDLH value for these chemicals was not exceeded. Calculated concentrations of ammonium hydroxide, hexone, nitric acid, propane, gasoline, chlorine and liquid nitrogen were all below the TLV-STEL value. 
1.0 INTRODUCTION AND BACKGROUND .................... 1

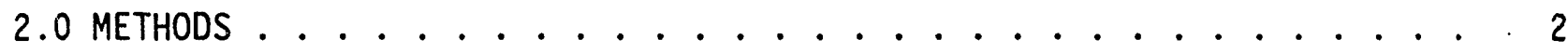

3.0 RESULTS .......................... 12

3.1 Ammonium Hydroxide . . . . . . . . . . . . . . . . . . . 12

3.2 Hexone ................... 13

3.3 Nitrogen .................. 13

3.4 Nitric Acid . . . . . . . . . . . . . . . 14

3.5 Hydrofluoric Acid . . . . . . . . . . . . . 15

3.6 Propane . . . . . . . . . . . . . . . . . . . . . . . 17

3.7 Gasoline .................... . . 18

3.8 Anhydrous Ammonia . . . . . . . . . . . . . . . 18

3.9 Chlorine .................. 20

4.0 SUMMARY . . . . . . . . . . . . . . . . 22

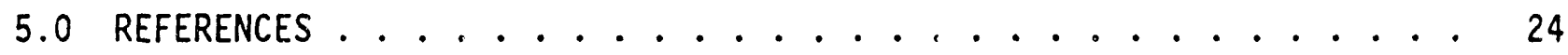

APPENDIX A - CALCULATION OF 95\% AND 50\% METEOROLOGICAL CONDITIONS FROM A JOINT FREQUENCY DISTRIBUTION . . . . A-1

A-1 BASIC METHODOLOGY AND DATA ......... A-3 A-2 $50 \%$ AND $95 \%$ CHI/O VALUES FOR THE SE SECTOR ....... A-6

\section{LIST OF TABLES}

1.1 Results of the preliminary chemical evaluation found in reference [1]

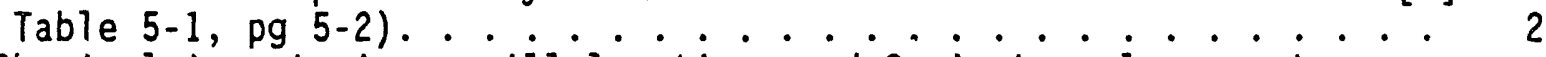

2.1 Chemical inventories, spill locations and 2 minute release rates for the chemicals identified in Reference [3]. ........ 3

2.2 Density, molecular weight and TLV-STEL and IDLH values for chemicals used in the evaluation. The reference numbers refer to the density and molar weight values. $\dot{v}$ a for stability $\dot{c}$ lass $\dot{F}$.

2.3 Values for factors $a$ and $b$ in Equation 2 for stability class $\vec{F}$.
These values were obtained from reference [7] and $\sigma_{x}$ is equal to

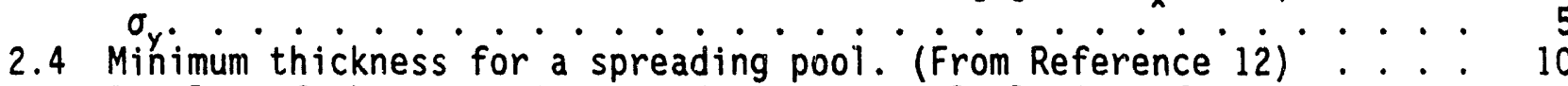

3.1 Results of the screening air dispersion calculations for ammonium hydroxide. . . . . . . . . . . . . 12

3.2 Results of the screening air dispersion calculations for

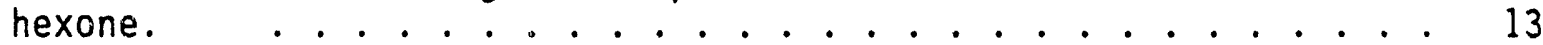

3.3 Results of the screening air dispersion calculations for nitrogen. . 14 
3.4 Results of the screenilig air dispersion calculations for nitric acid. 14

3.5 Results of the screening air dispersion calculations for hydrofluoric acid release at ICPP. . . . . . . . . . . . . . 15

3.6 Results of the screening air dispersion calculations for hydrofluoric acid rnlease at Lincoln Blvd (95\% meteorological conditions).

3.7 A comparison of the $50 \%$ and $95 \%$ release rates and release time for an HF spill on Lincoln Blvd.

3.8 Results of the air dispersion calculations for hydrofluoric acid release at Lincoln Blvd using 50\% meteorological conditions.

3.9 Results of the air dispersion calculations for a propane release at Lincoln Blvd using 95\% meteorological conditions. . . . . . . . . 18

3.10 Results of the screening air dispersion calculations for gasoline. . . . . . . . . . . . . . . . . . . . 18

3.11 Results of air dispersion calculations for an instantaneous release of anhydrous ammonia. . . . . . . . . . . . . . . . . 19

3.12 Results of a six minute release of anhydrous ammonia from a 65,500 $\mathrm{kg}$ tank using $95 \%$ and $50 \%$ meteorological conditions. . . . . . . . 20

3.13 Results from air dispersion modeling for a $123 \mathrm{~kg}$ instantaneous release of chlorine.

3.14 Results from air dispersion modeling for a $68 \mathrm{~kg}$ instantaneous release of chlorine. . . . . . . . . . . . . . . . . . .

4.1 Summary of the air dispersion calculations for the 1 in level at the ATR facility. . . . . . . . . . . . . . . . . . . .

A-1 Wind speed classes used in $95 \%$ and $50 \%$ met calculations. $\cdot$.

A-2 Number of hours wind blew in first wind speed class in each of the 16 sectors for each stability class.

A-3 Number of calm hours added to the first wind speed class in each of the 16 sectors for each stability class.

A-4 Formulas used in determination of $\sigma_{y}$ and $\sigma_{z}$. (from Moore et a)., 1979.)

A-5 CHI/Q values and fraction of time the wind blew at a particular stability class and wind speed for the SE sector of the $10 \mathrm{~m}$ level Grid III meteorological station.

A-5 Time weighted CHI/Q values fraction of $\dot{C} H \dot{L} / \dot{Q}$ values less than the given value for the SE sector of GRID III.

\section{LIST OF FIGURES}

2.1 Modeling region showing ICPP and Lincoln Blvd spill locations and ATR and TRA guard stations locations. 


\section{ASSESSMENT OF IMPACTS AT THE ADVANCED TEST REACTOR AS A RESULT \\ OF CHEMICAL RELEASES AT THE IDAHO CHEMICAL PROCESSING PLANT}

\subsection{INTRODUCTION AND BACKGROUND}

The purpose of this report is to document the methods used to estimate potential air concentrations at the Advanced Test Reactor (ATR) facility resulting from a chemical spill at or near the Idaho Chemical Processing Plant (ICPP). This work is intended to provide a measure of potential impact on the ATR reactor control room habitability after a chemical spill at ICPP.

Airborne chemical concentrations in the control room were not estimated, rather, airborne concentrations at the ATR air intake port, at ground level and at the Test Reactor Area (TRA) guard station were evaluated.

A preliminary evaluation of a limited set of chemicals was performed by $C$. Sulivan and S. Eide (1990) [1]. The preliminary evaluation was performed according to the guidance provided in U.S. Atomic Energy Commission Regulatory Guide 1.78 [2]. The results of this evaluation (Table 1.1) showed none of the chemicals evaluated could be el iminated from further consideration based on comparison with the Threshold Limit Value, Short Term Exposure Limit (TLVSTEL) [3] and the Immediately Dangerous to Life and Health (IDLH) [4]. The TLV-STEL is a 15 minute time weighted average exposure which should not be exceeded at any time during the workday. Exposures above the STEL may or may not be exceeded for any period of time depending on the chemical. The IDLH is defined as the maximum concentration from which, in the event of a respirator failure, one could escape within 30 minutes without experiencing any escapeimpairing or irreversible health effects.

This paper documents several sets of dispersion calculations which use a more refined set of assumptions than the calculations performed with the methodology given in Regulatory Guide 1.78. Several of the refinements include evaluation of the evaporation rate of the chemical, 15 and 30 minute time averaged concentrations, evaluation of receptor distance and evaluation of the potential spill area. These calculations were performed for the 
chemicals listed in Table 1.1 and some additional chemicals identified as potentially hazardous.

Table 1.1 Results of the preliminary chemical evaluation found in reference [1] (Table 5-1, pg 5-2).

\begin{tabular}{|l|c|c|c|c||}
\hline \hline Chemical & Quantity & TLV-STEL & IDLH & $\begin{array}{c}\text { Conc. at } \\
\text { ATR }\end{array}$ \\
\hline \hline & $(\mathrm{L})$ & $\left(\mathrm{mg} / \mathrm{m}^{3}\right)$ & $\left(\mathrm{mg} / \mathrm{m}^{3}\right)$ & $\left(\mathrm{mg} / \mathrm{m}^{3}\right)$ \\
\hline \hline Liquid Nitrogen & 5,000 & $\ldots \ldots-$. & $1.18 \mathrm{E}+04$ & $1.59 \mathrm{E}+04$ \\
\hline $\begin{array}{l}\text { Ammonium } \\
\text { Hydroxide }\end{array}$ & 1,000 & $2.70 \mathrm{E}+01$ & $3.50 \mathrm{E}+02$ & $2.31 \mathrm{E}+04$ \\
\hline Hexone & 4,500 & $3.00 \mathrm{E}+02$ & $1.23 \mathrm{E}+04$ & $8.72 \mathrm{E}+04$ \\
\hline Nitric Acid & 129,690 & $1.00 \mathrm{E}+01$ & $2.60 \mathrm{E}+02$ & $6.84 \mathrm{E}+05$ \\
\hline $\begin{array}{l}\text { Hydrofluoric } \\
\text { Acid }\end{array}$ & 30,280 & $2.50 \mathrm{E}+00$ & $2.50 \mathrm{E}+01$ & $4.46 \mathrm{E}+04$ \\
\hline
\end{tabular}

\subsection{METHODS}

The first set of calculations performed were screening in nature. The purpose of these calculations was to evaluate the 15 and 30 minute time average concentration and also screen out any of the new chemicals added to the list. These averaged concentrations correspond to the TLV-STEL and IDLH exposure limits respectively. Chemical inventories were supplied by J. Tozer [5] (Table 2.1). Some of the inventories were given in terms of volumes. Air dispersion modeling requires the inventory to be represented as a mass. This conversion requires some knowledge of the chemical's density. The chemical densities used in this analysis are listed in Table 2.2.

The INPUFF code [6] was used to model contaminant dispersion in the atmosphere. The INPUFF code was developed for US EPA and models continuous, non-steady state releases using a series of overlapping puffs. The INPUFF code also allows the user to calculate the air concentration as a function of time at a specified receptor point. 
For some chemicals, an instantaneous release was assumed. In this case, the instantaneous Gaussian puff equation [2] for a ground level release and ground level receptor was used. The concentration is given by Equation (1).

Table 2.1 Chemical inventories, spill locations and 2 minute release rates. for the chemicals identified in Reference [3].

\begin{tabular}{|c|c|c|c|c|c|}
\hline \multirow[t]{2}{*}{ Chemical } & \multirow{2}{*}{$\begin{array}{c}\text { Spill } \\
\text { Location }\end{array}$} & \multirow{2}{*}{$\begin{array}{l}\begin{array}{l}\text { Release } \\
\text { Rate }\end{array} \\
(g / s)\end{array}$} & \multicolumn{3}{|c|}{ Quantity } \\
\hline & & & (gal) & (1bs) & $(\mathrm{kg})$ \\
\hline $\begin{array}{l}\text { Ammonium } \\
\text { Hydroxide }\end{array}$ & $\begin{array}{l}\text { Lincoln Blvd } \\
\text { Turn off } \\
\end{array}$ & $6.25 E+3$ & $2.20 E+02$ & & $7.49 E+02$ \\
\hline Hexone & $\begin{array}{l}\text { Lincoln Blud } \\
\text { Turn off }\end{array}$ & $2.78 E+4$ & $1.10 E+03$ & & $3.33 E+03$ \\
\hline $\begin{array}{l}\text { Liquid } \\
\text { Nitrogen }\end{array}$ & $\begin{array}{l}\text { Lincoln Bivd } \\
\text { Turn off }\end{array}$ & $1.67 E+5$ & & $4.40 E+04$ & $2.00 E+04$ \\
\hline $\begin{array}{l}\text { Nitric } \\
\text { Acidic } \\
\end{array}$ & $\begin{array}{l}\text { South side } \\
\text { Bldg } 621\end{array}$ & $2.23 E+6$ & $5.20 E+04$ & & $2.68 E+05$ \\
\hline $\begin{array}{l}\text { Hydrofluo- } \\
\text {-ric Acid }\end{array}$ & $\begin{array}{l}\text { South side } \\
\text { Bldg } 621 \\
\end{array}$ & $3.17 E+5$ & $8.00 E+03$ & & $3.81 E+04$ \\
\hline $\begin{array}{l}\text { Hydrofluo- } \\
\text {-ric Acid }\end{array}$ & $\begin{array}{l}\text { Lincoln Bivd } \\
\text { Turn off } \\
\end{array}$ & $1.71 E+5$ & $4.30 E+03$ & & $2.05 E+04$ \\
\hline Propane & $\begin{array}{l}\text { Lincoln Blvd } \\
\text { Turn off }\end{array}$ & $4.57 E+4$ & $2.50 E+03$ & & $5.49 E+03$ \\
\hline Gasoline & $\begin{array}{l}\text { Lincoln Blvd } \\
\text { Turn off }\end{array}$ & $5.05 E+4$ & $2.00 E+03$ & & $0.06 E+03$ \\
\hline $\begin{array}{l}\text { Anhydrous } \\
\text { Ammonia }\end{array}$ & $\begin{array}{l}\text { South side } \\
\text { Bldg } 649\end{array}$ & $1.36 E+4$ & & $3.60 E+03$ & $1.64 E+03$ \\
\hline $\begin{array}{l}\text { Anhydrous } \\
\text { Ammonia }\end{array}$ & Near Bldg 605 & $5.45 E+5$ & & $1.44 E+05$ & $6.55 E+04$ \\
\hline Chlorine & Near Bldg 716 & $1.02 E+3$ & & $2.70 E+02$ & $1.23 E+02$ \\
\hline
\end{tabular}


Table 2.2 Density, molecular weight and TLV-STEL and IDLH values for chemicals used in the evaluation. The reference numbers refer to thie density and molar weight values.

\begin{tabular}{|c|c|c|c|c|c|}
\hline \multirow[t]{2}{*}{ Chemical } & Density & MW & TLV-STEL & IDLH & \multirow[t]{2}{*}{ Reference } \\
\hline & $\left(\mathrm{g} / \mathrm{cm}^{3}\right)$ & $\mathrm{g} / \mathrm{mol}$ & $\left(\mathrm{mg} / \mathrm{m}^{3}\right)$ & $\left(\mathrm{mg} / \mathrm{m}^{3}\right)$ & \\
\hline Ammonium Hydroxide & $0.90(20 \mathrm{C})$ & 17.8 & $2.70 E+01$ & $3.50 E+02$ & [9] \\
\hline Hexone & $0.80(20 \mathrm{C})$ & 100.2 & $3.00 E+02$ & $1.23 E+04$ & [9] \\
\hline Liquid Nitrogen & 0.808 & 14 & & $1.18 \mathrm{E}+04$ & [14] \\
\hline Nitric Acid $(60 \%)$ & $1.36(25 \mathrm{C})$ & 63 & $1.00 E+01$ & $2.60 E+02$ & [9] \\
\hline $\begin{array}{l}\text { Hydrofluoric Acid } \\
(70 \%)\end{array}$ & $1.26(20 \mathrm{C})$ & 20 & $2.50 E+00$ & $2.50 E+01$ & [9] \\
\hline Propane & 0.58 & $\mathrm{n} / \mathrm{u}$ & $1.80 E+03$ & $3.60 E+04$ & [14] \\
\hline Gasoline & 0.80 & $n / u$ & $9.00 E+02$ & $1.50 E+03$ & [14] \\
\hline Anhydrous Ammonia & 0.77 & 17.3 & $2.40 E+01$ & $3.50 E+02$ & {$\left[\begin{array}{lll}14 & \& & 4\end{array}\right]$} \\
\hline Chlorine & 1.47 & 71.0 & $3.00 E+00$ & $9.00 E+01$ & {$\left[\begin{array}{lll}14 & \& & 4\end{array}\right]$} \\
\hline
\end{tabular}

$\mathrm{n} / \mathrm{u}$ Not used in calculations 


$$
C(x, y, t)=\frac{Q}{\sigma_{x}^{n} \sigma_{y} \sigma_{z}^{2} 2^{0.5} \pi^{3 / 2}} \operatorname{EXP}\left(-0.5\left(\frac{X-u t}{\sigma_{x}}\right)^{2}\right) \operatorname{EXP}\left(-0.5\left(\frac{y}{\sigma_{y}}\right)^{2}\right)
$$

where $C(x, y, t)=$ concentration as a function of distance and time $\left(\mathrm{g} / \mathrm{m}^{3}\right)$

$u=$ wind speed $(\mathrm{m} / \mathrm{s})$

$\sigma_{x, y, z}=$ standard deviation of the plume in the $x, y$ and $z$ direction $(m)$

$Q=$ mass released $(g)$

$X=$ distance along plume centerline (m)

$y=$ distance perpendicular to plume centerline (m)

The $\sigma_{x, y, z}$ values are given by Kunkel for P-G stability categories [7]

$$
\sigma_{x_{1}, \ldots, z}=a x^{b}
$$

where $a$ and $b$ are given in Table 2.3 for stability class $F$.

Table 2.3 Values for factors $a$ and $b$ in Equation 2 for stability class $F$. These values were obtained from reference [7] and $\sigma_{x}$ is equal $t$ ? $\sigma_{y}$.

\begin{tabular}{|c|c|c|}
\hline Factors & $\sigma_{x, y}$ & $\sigma_{z}$ \\
\hline$a$ & 0.076 & 0.9990 \\
\hline$b$ & 0.90 & 0.4052 \\
\hline
\end{tabular}

Two receptor locations were identified. The first location was $1 \mathrm{~m}$ above ground level (AGL) at the ATR facility. The air intake for ventilation in the facility is located $4.8 \mathrm{~m} \mathrm{AGL}$. Scoping calculations indicated little difference between the ground level concentration and the concentration at 4.8 $\mathrm{m}$. For simplicity only the $1 \mathrm{~m}$ elevation was reported because it approximates breathing height and would adequately represent both receptor locations (ground level and $4.8 \mathrm{~m}$ ). The second receptor was located at the Test Reactor Area's guard station at the $1 \mathrm{~m}$ height. The wind was assumed to 
blow such that ATR would lie along the centerline of the contaminant plume created by the spilled chemical. The TRA guard station would be located off plume centerline. Two spill locations were modeled. Spills occurring at ICPP were assumed to occur at the NW corner of the ICPP industrial complex. Individual spill locations at the ICPP were not explicitly modeled. Chemical transport accidents were assumed to result in a chemical spill at the junction of Lincoln Blvd and the east road to ICPP. All straight line plume paths from the spill to ATR were in the NW sector relative to the spill location.

The ATR facility was $2.9 \mathrm{~km}, \mathrm{~N} 55 \mathrm{~W}$ from the NW corner of the ICPP facility where the spill was postulated to occur. The distance and direction from the ICPP spill to the TRA guard station was $2.5 \mathrm{~km}, \mathrm{~N} 55 \mathrm{~W}$ and $0.143 \mathrm{~km} \mathrm{~S} 35 \mathrm{~W}$. The straight line distance from the Lincoln Blvd spill to ATR was $2.6 \mathrm{~km}$ in the direction $\mathrm{N} 45 \mathrm{~W}$. The distance and direction from the Lincoln Bivd spill to the TRA guard station was $2.2 \mathrm{~km} \mathrm{~N} 45 \mathrm{~W}$, and $71 \mathrm{~m} \mathrm{~S} 45 \mathrm{~W}$.

The initial scoping calculations assumed the following:

1. The entire inventory of the chemical becomes airborne over a two minute period. For chemicais with boiling points below ambient temperatures, the release was assumed to be inst intaneous.

2. The effective plume rise was $1.0 \mathrm{~m}$ (This is the minimum plume height allowed by INPUFF)

3. The release occurred over an area of $1 \mathrm{~m}^{2}$. This essentially results in a point source release. For chemicals released instantaneously, the initial volume of the plume was assumed to be $0 \mathrm{~m}^{3}$.

4. A lid (mixing) height of $600 \mathrm{~m}$ was assumed. This is the mixing height used for INEL radiological assessment calculations.

5. A wind speed of $2 \mathrm{~m} / \mathrm{s}$, stability class $\mathrm{F}$, and ambient temperature of $27 \mathrm{C}$ was selected to represent the $95 \%$ worst case meteorological conditions [8]. (See Appendix A dor definition of $95 \%$ meteorological conditions). 


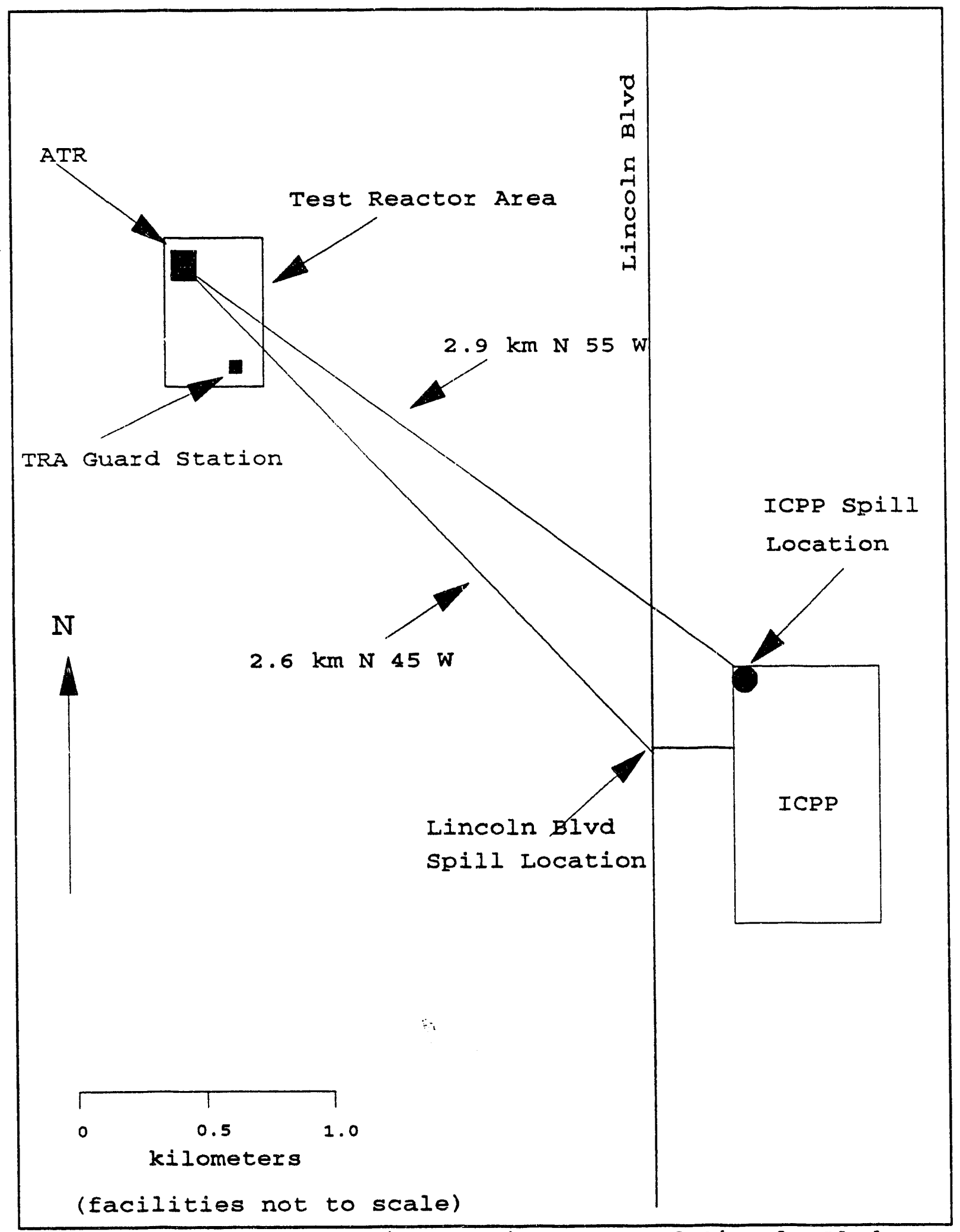

Figure 2.1 Modeling region showing ICPP and Lincoln Blvd spill locations and ATR and TRA guard station locations. 
The release time of two minutes was selected based on the similar analysis performed for the Special Isotope Separation Facility [9]. This release assumes the "flash off" component and any remaining chemical mass evaporates over a two minute period. Evaporative release models such as SPILLS [10] assume any flash off component occurs during the first minute of the accident and the remainder evaporates over time.

Three concentrations were evaluated; the peak (or maximum) concentration, the 15 minute average concentration and 30 minute average concentration. The 15 and 30 minute average concentration was calculated by dividing the maximum integrated concentration by either 15 or 30 minutes. The average concentrations are given by Equation (3)

$$
C_{a v g}=\frac{\int_{0}^{t_{p}} C(x, y, t) d t}{t_{\text {avg }}}
$$

where $t_{\text {avg }}=$ the averaging time and $t_{p}=$ plume passage time.

Chemicals for which peak concentration did not exceed the TLV-STEL value were eliminated from consideration. If the peak concentration exceeded the TLVSTEL but the 15 minute average concentration was less than the TLV-STEL, then the chemical was eliminated from further evaluation. If the TLV-STEL value exceeded the 15 minute average and peak concentration, but the 30 min average concentration was less than the IDLH limit, then the chemical was either reevaluated or eliminated from consideration based on the assumed release scenario and physical and chemical properties of the chemical.

Release of chemicals with high vapor pressures (greater than 1 atm, such as chlorine and anhydrous ammonia) are governed mainly by the rate of release from the holding vessel. Release of chemicals with relatively high vapor pressures but are liquid at ambient temperatures (hydrofluoric acid) are governed primarily by the evaporation rate of the chemical. The release rate 
of a liquidfied gas through an exit hole located below the liquid ievel in a tank is given by Equation (4) [11].

$$
q_{1}=C_{d} A \rho_{I} \sqrt{2 g h+\frac{2\left(P-P_{a}\right)}{\rho_{1}}}
$$

$$
\begin{aligned}
& Q_{1}=\text { release rate }(\mathrm{kg} / \mathrm{s}) \\
& P_{a}=\text { atmospheric pressure }(1.0 E+05 \mathrm{~Pa}) \\
& C_{d}=\text { Coefficient of discharge }(0.8) \\
& A=\text { Area of exit hole } \mathrm{m}^{2} \\
& g=\text { gravitational acceleration }\left(\mathrm{m} / \mathrm{s}^{2}\right) \\
& h=\text { height of liquid above exit hole }(\mathrm{m}) \\
& P=\text { vapor pressure of } 1 \text { iquid }(\mathrm{Pa}) \\
& \rho_{l}=\text { the liquid density }\left(\mathrm{kg} / \mathrm{m}^{3}\right)
\end{aligned}
$$

For chemical releases evaluated with Equation 4, the pressure differential between the tank and atmosphere dominated the release of the chemical from the tank. Thus, the height of the liquid in the tank was ignored. The mass released from the tank was assumed to be in the gaseous state and become airborne once released.

Chemicals with lower vapor pressures (approximately 0.5 atm at 27 degrees C) were assumed to be released primarily as a liquid. The subsequent evaporation of the chemical was the means by which the chemical was released to the atmosphere. The liquid release was assumed to be instantaneous. Spills not contained in physical structures were assumed to spread out over an area given by

$$
A=\frac{V}{T}
$$

where $A=$ area of the spill $\left(\mathrm{m}^{2}\right)$

$V=$ volume of spill $\left(\mathrm{m}^{3}\right)$ 


$$
T=\text { thickness of spill (m) }
$$

The thickness of the spill depended on the wher? the spill occurred. The minimum thickness of a spill (Table 2.4) was reported in Reference [12] for a variety of surfaces.

Table 2.4 Minimum thickness for a spreading pool. (From Reference 12)

\begin{tabular}{||l|c|}
\hline \multicolumn{1}{|c|}{ Surface } & Thickness (mm) \\
\hline \hline Rough, sandy soil & 25 \\
\hline Farml and, pasture & 20 \\
\hline Smooth sand, gravel & 10 \\
\hline Smooth sand, concrete, store & 5 \\
\hline
\end{tabular}

Spills which occurred on Lincoln Blvd were assumed to originate from the center of the roadway and spread equally in both directions creating a square with a thickness of $5 \mathrm{~mm}$. The width of the road was reported to be $12.2 \mathrm{~m}$, thus, the total area of the spill on the road was $148.8 \mathrm{~m}$. The volume of liquid on the road was

$V=148.8 \mathrm{~m}^{2} \times 0.005 \mathrm{~m}=0.744 \mathrm{~m}^{3}$

The remaining liquid was assumed to spread equally on both sides of the road to a thickness of $25 \mathrm{~mm}$. The width of the spill was assumed to be $12.2 \mathrm{~m}$ and the length was given by

$$
L=\frac{V_{t}-V_{z}}{(0.025 m)(12.2 m)}
$$

where $L=$ the length (perpendicular to the roadway) of one side of the spili (m)

$$
\begin{aligned}
& V_{t}=\text { total volume of spill }\left(\mathrm{m}^{3}\right) \\
& V_{r}=\text { volume of spill on roadway }\left(\mathrm{m}^{3}\right)
\end{aligned}
$$


Evaporation of the chemical after the spill was given by Kunkel [7] using clewert's equation.

$$
Q=\frac{1.333 U^{3 / 4} A\left(1+0.0043 T_{p}^{2}\right) M W V p}{M W H V p H}
$$

where $Q=$ the evaporation rate $(\mathrm{g} / \mathrm{min})$

$U=$ the wind speed $(\mathrm{m} / \mathrm{s})$

$A=$ the area of the pool $\left(\mathrm{m}^{2}\right)$

$T_{p}=$ the pool temperature $(C)$

$M W=$ molecular weight $(\mathrm{g} / \mathrm{mole})$

$V p=$ the vapor pressure (atm)

MWH = the molecular weight of hydrazine $(32.045 \mathrm{~g} / \mathrm{mole})$

$\mathrm{VpH}=$ the vapor pressure of hydrazine $(0.02113 \mathrm{~atm})$

The area of the pool was assumed to remain constant until the chemical was completely evaporated. This was a conservative assumption since release rate is proportional to area of the spill and the area would likely decrease during evaporation.

For some chemicals, an analysis using $50 \%$ meteorological conditions was performed. The 50\% meteorological conditions for the SE sector (the sector the wind must blow FROM to affect the NW sector) was stability class $D$ and $13.2 \mathrm{~m} / \mathrm{s}$ wind speed. These conditions only represent the $50 \%$ meteorological conditions when the wind blows from the SE sector. The fraction of time the wind blows in the SE sector was not factored into the calculation. Methodology used to calculate the $50 \%$ meteorological conditions was discussed with the Idaho Falls National Oceanic and Atmospheric Administration (NOAA) personnel and a copy of the calculation was forwarded for review. The methodology is presented in Appendix $A$. 


\subsection{RESULTS}

The chemicals evaluated in this study varied in composition, toxicity and physical properties. Screening procedures varied for each chemical and comparison of results was not always valid. For this reason, it was decided to present the results of the calculations on chemical by chemical basis. A final summary will be presented in the Section 4.0 of this document.

\subsection{Ammonium Hydroxide}

Ammonium hydroxide $\left(\mathrm{NH}_{4} \mathrm{OH}\right)$ was initially evaluated using the 2 minute release scenario ( $\mathrm{Tab}$ le 3.1). $\mathrm{NH}_{4} \mathrm{OH}$ was assumed to be $14 \mathrm{Molar}$ concentration as stated in the SIS SAR [9]. The peak concentration and 15 minute average concentration exceeded the TLV-STEL $\left(27 \mathrm{mg} / \mathrm{m}^{3}\right)$ value, however, the 30 minute average concentration did not exceed the IDLH value $\left(350 \mathrm{mg} / \mathrm{m}^{3}\right)$ at either the ATR facility and TRA guard station.

Table 3.1 Results of the screening air dispersion calculations for ammonium hydroxide.

\begin{tabular}{||c|c|c|}
\hline \multirow{2}{*}{ Concentration Type } & ATR Facility & TRA Guard Station \\
\cline { 2 - 3 } & $\left(\mathrm{mg} / \mathrm{m}^{3}\right)$ & $\left(\mathrm{mg} / \mathrm{m}^{3}\right)$ \\
\hline Peak Concentration & $4.23 \mathrm{E}+02$ & $3.39 \mathrm{E}+02$ \\
\hline 15 Minute Average & $6.56 \mathrm{E}+01$ & $4.93 \mathrm{E}+01$ \\
\hline 30 Minute Average & $3.28 \mathrm{E}+01$ & $2.47 \mathrm{E}+01$ \\
\hline
\end{tabular}

The peak concentration exceeded the TLV-STEL $\left(27 \mathrm{mg} / \mathrm{m}^{3}\right)$ by 16 times, thus, it was decided to perform an additional analysis. The entire inventory of $\mathrm{NH}_{4} \mathrm{OH}$ was assumed to be spilled at the Lincoln Blyd. location. The area occupied by the spill, assuming a spill thickness of $0.005 \mathrm{~m}$, was $166.6 \mathrm{~m}^{2}$. For conservatism, the spill thickness was assumed to be $0.005 \mathrm{~m}$ for the entire spill. The evaporation rate calculated using Equation 7, 95\% meteorological conditions and a vapor pressure of $0.398 \mathrm{~atm}$ for $14 \mathrm{M} \mathrm{NH}_{4} \mathrm{OH}$ (Perry and Chilton [13], pg 3-68) was $268 \mathrm{~g} / \mathrm{s}$. The total release time was 46.6 minutes. The release time was sufficiently long enough to allow for steady state conditions 
to be established, thus the peak concentration was equal to the 15 and 30 minute average concentrations. The peak concentration at ATR was $21.5 \mathrm{mg} / \mathrm{m}^{3}$ and $16.0 \mathrm{mg} / \mathrm{m}^{3}$ at the TRA guard station. These values were below the TLV-STEL value thus $\mathrm{NH}_{4} \mathrm{OH}$ was eliminated from further consideration.

\subsection{Hexone}

Hexone was evaluated using the 2 minute release scenario (Table 3.2). The peak concentration exceeded the TLV-STEL $\left(300 \mathrm{mg} / \mathrm{m}^{3}\right)$ value at both the ATR facility and TRA guard station. However the 15 minute and 30 minute average concentration did not exceed the TLV-STEL value or the IDLH value (1.23E+04 $\left.\mathrm{mg} / \mathrm{m}^{3}\right)$. For these reasons, hexone was el iminated from further evaluation.

Table 3.2 Results of the screening air dispersion calculations for hexone.

\begin{tabular}{|l|c|c|}
\hline \multirow{2}{*}{ Concentration Type } & ATR Facilty & TRA Guard Station \\
\cline { 2 - 3 } & $\left(\mathrm{mg} / \mathrm{m}^{3}\right)$ & $\left(\mathrm{mg} / \mathrm{m}^{3}\right)$ \\
\hline Peak Conceniration & $1.88 \mathrm{E}+03$ & $1.50 \mathrm{E}+03$ \\
\hline 15 Minute Average & $2.91 \mathrm{E}+02$ & $2.19 \mathrm{E}+02$ \\
\hline 30 Minute Average & $1.45 \mathrm{E}+02$ & $1.10 \mathrm{E}+02$ \\
\hline
\end{tabular}

\subsection{Nitrogen}

The boiling point of nitrogen is much less than the assumed ambient temperature, thus, nitrogen was evaluated using an instantaneous release scenario (Table 3.3) and Equation 1. Only an IDLH value was available for nitrogen. The peak concentration exceeded the IDLH $\left(1.18 \mathrm{E} 04 \mathrm{mg} / \mathrm{m}^{3}\right)$ value at the ATR facility, however, the 15 minute and 30 minute average concentration did not. The peak concentration did not exceed the IDLH value at the TRA guard station. For these reasons, nitrogen was el iminated from further evaluation. 
Table 3.3 Results of the screening air dispersion calculations for nitrogen.

\begin{tabular}{||c|c|c|}
\hline \multirow{2}{*}{ Concentration Type } & ATR Facilty & TRA Guard Station \\
\cline { 2 - 3 } & $\left(\mathrm{mg} / \mathrm{m}^{3}\right)$ & $\left(\mathrm{mg} / \mathrm{m}^{3}\right)$ \\
\hline Peak Concentration & $1.30 \mathrm{E}+04$ & $1.05 \mathrm{E}+03$ \\
\hline 15 Minute Average & $1.60 \mathrm{E}+03$ & $1.30 \mathrm{E}+03$ \\
\hline 30 Minute Average & $8.20 \mathrm{E}+02$ & $6.56 \mathrm{E}+02$ \\
\hline
\end{tabular}

\subsection{Nitric Acid}

Nitric Acid $\left(\mathrm{HNO}_{3}\right)$ was initially evaluated using a 2 minute release scenario (Table 3.4). The peak concentration, 15 and 30 minute average concentration exceeded the TLV-STEL $\left(1.0 \mathrm{mg} / \mathrm{m}^{3}\right)$ and IDLH value $\left(260 \mathrm{mg} / \mathrm{m}^{3}\right)$ respectively at both the ATR facility and TRA guard station. All applicable $\mathrm{HNO}_{3}$ limits were exceeded, thus, additional analyses were performed. The entire inventory of nitric acid was assumed to be released into the containment wall surrounding the tank. The area of the containment wall was given by Tozer [5] to be 250 $\mathrm{m}^{2}$. The evaporation rate celculated using Equation 7 , $95 \%$ meteorological conditions and a vapor pressure of 0.013 atm for $60 \% \mathrm{HNO}_{3}$ (Perry and Chilton, pg 3-65) was $46.85 \mathrm{~g} / \mathrm{s}$. The total release time was 66 days and was sufficiently long enough to allow for steady state conditions to be established, thus the peak concentration was equal to the 15 and 30 minute average concentrations. The peak concentration at ATR was $3.3 \mathrm{mg} / \mathrm{m}^{3}$ and 0.72 $\mathrm{mg} / \mathrm{m}^{3}$ at the TRA guard station. These values were below the TLV-STEL value, thus, $\mathrm{HNO}_{3}$ was eliminated from further consideration.

Table 3.4 Results of the screening air dispersion calculations for nitric acid.

\begin{tabular}{||c|c|c|}
\hline \multirow{2}{*}{ Concentration Type } & ATR Facilty & TRA Guard Station \\
\cline { 2 - 3 } & $\left(\mathrm{mg} / \mathrm{m}^{3}\right)$ & $\left(\mathrm{mg} / \mathrm{m}^{3}\right)$ \\
\hline Peak Concentration & $1.23 E+05$ & $3.02 \mathrm{E}+04$ \\
\hline 15 Minute Average & $1.97 \mathrm{E}+04$ & $4.64 \mathrm{E}+03$ \\
\hline 30 Minute Average & $9.85 \mathrm{E}+03$ & $2.32 \mathrm{E}+03$ \\
\hline
\end{tabular}




\subsection{Hydrofluoric Acid}

Two hydrofluoric acid (HF) release scenarios were evaluated; a release from a tank located at ICPP and a spill on Lincoln BIvd. Both scenarios were initially evaluated using a 2 minute release (Table 3.5 and 3.6). The peak concentration, 15 and 30 minute average concentration exceeded the TLV-STEL $\left(2.5 \mathrm{mg} / \mathrm{m}^{3}\right)$ and IDLH value $\left(25 \mathrm{mg} / \mathrm{m}^{3}\right)$ respectively at both the ATR facility and TRA guard station for both release scenarios.

Table 3.5 Results of the screening air dispersion calculations for hydrofluoric acid release at ICPP.

\begin{tabular}{||c|c|c|}
\hline \hline \multirow{2}{*}{ Concentration Type } & ATR Facilty & TRA Guard Station \\
\cline { 2 - 3 } & $\left(\mathrm{mg} / \mathrm{m}^{3}\right)$ & $\left(\mathrm{mg} / \mathrm{m}^{3}\right)$ \\
\hline Peak Concentration & $1.75 \mathrm{E}+04$ & $4.30 \mathrm{E}+03$ \\
\hline 15 Minute Average & $2.80 \mathrm{E}+03$ & $6.60 \mathrm{E}+02$ \\
\hline 30 Minute Average & $1.40 \mathrm{E}+03$ & $3.30 \mathrm{E}+02$ \\
\hline
\end{tabular}

Table 3.6 Results of the screening air dispersion calculations for hydrofluoric acid release at Lincoln Blvd (95\% meteorological conditions).

\begin{tabular}{|l|c|c|}
\hline \multirow{2}{*}{ Concentration Type } & ATR Facilty & TRA Guard Station \\
\cline { 2 - 3 } & $\left(\mathrm{mg} / \mathrm{m}^{3}\right)$ & $\left(\mathrm{mg} / \mathrm{m}^{3}\right)$ \\
\hline Peak Concentration & $1.16 \mathrm{E}+04$ & $9.25 \mathrm{E}+03$ \\
\hline 15 Minute Average & $1.79 \mathrm{E}+03$ & $1.35 \mathrm{E}+03$ \\
\hline 30 Minute Avcrago & $8.95 \mathrm{E}+02$ & $6.75 \mathrm{E}+02$ \\
\hline
\end{tabular}

All applicable HF limits were exceeded, thus, additional analyses were performed. For the ICPP spill, the entire inventory of HF was assumed to be released into the containment wall surrounding the tank. The area of the containment wall was given by Tozer [5] to be $38.4 \mathrm{~m}^{2}$. The evaporation rate was calculated using Equation 7, 95\% meteorological conditions and a vapor pressure of $0.209 \mathrm{~atm}$ for $70 \% \mathrm{HF}$. The release rate was $36.6 \mathrm{~g} / \mathrm{s}$. The total release time was 12 days which was sufficiently long enough to allow for 
steady state conditions to be established, thus the peak concentration was equal to the 15 and 30 minute average concentrations. The peak concentration at ATR was $2.5 \mathrm{mg} / \mathrm{m}^{3}$ and $0.60 \mathrm{mg} / \mathrm{m}^{3}$ at the TRA guard station. These values were at or below the TLV-STEL value at both locations. A further analysis was not performed because the calculation was conservative to start with and the TLV-STEL value was technically, not exceeded. In addition, the ILDH value was not exceeded at any of the receptor locations.

For the Lincoln Blvd spill, the road spill model (Equation 5 and 6) was used. The total area of the spill (including chemical on and off the roadway) was $771 \mathrm{~m}^{2}$. The release rate from the spill area calculated with Equation 7 for $95 \%$ meteorological conditions was $734 \mathrm{~g} / \mathrm{s}$. The total release time was 466 minutes. The release time was sufficiently long to allow for steady state conditions to be achieved, thus peak concentration was equal to 15 and 30 minute average concentrations. The peak concentration was $54 \mathrm{mg} / \mathrm{m}^{3}$ at the ATR facilty and $43 \mathrm{mg} / \mathrm{m}^{3}$ at the TRA guard station. These concentration values were significantly above the TLV-STEL and IDLH limits. A second analysis (Table 3.7 ) was performed using $50 \%$ meteorological conditions.

Table 3.7 A comparison of the $50 \%$ and $95 \%$ release rates and release time for an HF spill on Lincoln Blvd.

\begin{tabular}{|l|c|c|}
\hline & $50 \%$ Meteorological & $95 \%$ Meteorological \\
\hline Release Rate $(\mathrm{g} / \mathrm{s})$ & $1.81 \mathrm{E}+05$ & $7.34 \mathrm{E}+02$ \\
\hline Release Time (min) & 1.8 & 466 \\
\hline
\end{tabular}

The $50 \%$ meteorological conditions (Stability class $D$ and $13.2 \mathrm{~m} / \mathrm{s}$ wind speed) are the conditions such the for a constant release, the concentration at the specified receptor point is not exceeded $50 \%$ of the time. Changing to $50 \%$ meteorological conditions, however, also changes the release rate since release rate is proportional to (wind speed) ${ }^{3 / 4}$. Since the release time was close to 2 minutes for the 50\% meteorological conditions, then the peak, 15 and 30 minute average concentrations were different. The results (Table 3.8) show a much higher peak concentration $\left(385 \mathrm{mg} / \mathrm{m}^{3}\right.$ at ATR), however, the 15 
minute average concentration is slightly lower and the 30 minute average concentration is near the IDLH value. Suffice it to say that even a limited spill of HF from a tank truck at the Lincoln Blvd turn-off presents a significant health hazard to personnel in the immediate vicinity and perhaps at the ATR facilty.

Table 3.8 Results of the air dispersion calculations for hydrofluoric acid release at Lincoln Blvd using $50 \%$ meteorological conditions.

\begin{tabular}{||c|c|c|}
\hline Concentration Type & ATR Facilty & TRA Guard Station \\
\hline & $\left(\mathrm{mg} / \mathrm{m}^{3}\right)$ & $\left(\mathrm{mg} / \mathrm{m}^{3}\right)$ \\
\hline Peak Concentration & $3.85 \mathrm{E}+02$ & $4.58 \mathrm{E}+02$ \\
\hline 15 Minute Average & $5.08 \mathrm{E}+01$ & $6.00 \mathrm{E}+01$ \\
\hline 30 Minute Average & $2.53 \mathrm{E}+01$ & $3.00 \mathrm{E}+01$ \\
\hline
\end{tabular}

\subsection{Propane}

The propane release scenario was dictated by the release scenario presented in the SIS SAR. This release scenario was an $80 \mathrm{gal} / \mathrm{min}$ release, draining the entire tank. The duration of the release for the propane tank considered in this problem was $31.25 \mathrm{~min}$. In order to initial screen the problem however, the entir? propane inventory was released in 2 minutes according to the screening methodology presented in Section 2. The peak concentration (Table 3.9) exceeded the TLV-STEL $\left(1800 \mathrm{mg} / \mathrm{m}^{3}\right)$ value but not the IDLH $\left(36,000 \mathrm{mg} / \mathrm{m}^{3}\right)$ value. The 15 and 30 minute average concentrations were below the TLV-STEL value, thus propane was elininated from further evaluation.

An additional requested task was to determine the minimum distance a propane release must be from ATR to maintain an ambient concentration below the LEL (Lower Explosive Limit, $39,000 \mathrm{mg} / \mathrm{m}^{3}$ ) and IDLH. This calculation used the $95 \%$ meteorological conditions and the $80 \mathrm{gal} / \mathrm{min}$ release to calculate concentrations. The minimum distance a propane release must be to maintain the ambient concentration below the IDLH was $100 \mathrm{~m}$. 
The minimum distance a propane release must be to maintain the ambient concentration below the LEL was $95 \mathrm{~m}$.

Table 3.9 Results of the air dispersion calculations for a propane release at Lincoln Blvd using 95\% meteorological conditions.

\begin{tabular}{||l|c|c|}
\hline \hline Concentration Type & ATR Facilty & TRA Guard Station \\
\hline & $\left(\mathrm{mg} / \mathrm{m}^{3}\right)$ & $\left(\mathrm{mg} / \mathrm{m}^{3}\right)$ \\
\hline Peak Concentration & $3.10 \mathrm{E}+03$ & $2.48 \mathrm{E}+03$ \\
\hline 15 Minute Average & $4.80 \mathrm{E}+02$ & $3.61 \mathrm{E}+02$ \\
\hline 30 Minute Average & $2.40 \mathrm{E}+02$ & $1.80 \mathrm{E}+02$ \\
\hline
\end{tabular}

\subsection{Gasoline}

Gasoline was evaiuated using the 2 minute release scenario (Table 3.10). The peak concentration exceeded the TLV-STEL $\left(900 \mathrm{mg} / \mathrm{m}^{3}\right)$ value at both the ATR facility and TRA guard station. However, the 15 minute and 30 minute average concentration did not exceed the TLV-STEL value or the IDLH value $(1.50+03$ $\mathrm{mg} / \mathrm{m}^{3}$ ). For these reasons, gasoline was eliminated from further evaluation.

Table 3.10 Results of the screening air dispersion calculations for gasoline.

\begin{tabular}{|l|c|c|}
\hline Concentration Type & ATR Facilty & TRA Guard Station \\
\hline & $\left(\mathrm{mg} / \mathrm{m}^{3}\right)$ & $\left(\mathrm{mg} / \mathrm{m}^{3}\right)$ \\
\hline Peak Concentration & $3.42 \mathrm{E}+03$ & $2.74 \mathrm{E}+03$ \\
\hline 15 Minute Average & $5.30 \mathrm{E}+02$ & $3.99 \mathrm{E}+02$ \\
\hline 30 Minute Average & $2.65 \mathrm{E}+02$ & $2.00 \mathrm{E}+02$ \\
\hline
\end{tabular}

\subsection{Anhydrous Ammonia}

Releases of anhydrous ammonia were evaluated initially using the instantaneous release scenario represented by Equation 1 and later the scenario represented by Equation 4 . The instantaneous release considered three releases; the 
release of $24,68 \mathrm{~kg}(150 \mathrm{lb})$ bottles, the release of cne, $68 \mathrm{~kg}$ bottle and the release of one $65,500 \mathrm{~kg}(144,000 \mathrm{lb})$ tank. The results of the instantaneous release scenario (Table 3.11) showed the TLV-STEL and IDLH limit values ( 24 and $350 \mathrm{mg} / \mathrm{m}^{3}$ respectively) were exceeded by the 15 and 30 minute average concentration for the $65,500 \mathrm{~kg}$ release. The peak concentration exceeded the TLV-STEL for the one bottle release. However the 15 and 30 minute average concentrations were below the TLV-STEL a:Id IDL.H. The peak and 15 minute average concentration exceeded the TLV STEL value for the 24 bottle release. However the 30 minute average concentration was not exceeded by the IDLH.

Table 3.11 Results of air dispersion calculations for an instantaneous release of anhydrous ammonia.

\begin{tabular}{||l|c|c|c||}
\hline $\begin{array}{l}\text { Concentration } \\
\text { Type }\end{array}$ & $\begin{array}{c}\text { Release Mass } \\
(\mathrm{kg})\end{array}$ & $\begin{array}{c}\text { ATR Facilty } \\
\left(\mathrm{mg} / \mathrm{m}^{3}\right)\end{array}$ & $\begin{array}{c}\text { TRA Guard } \\
\text { Station }\left(\mathrm{mg} / \mathrm{m}^{3}\right)\end{array}$ \\
\hline Peak Conc. & $1.64 \mathrm{E}+03$ & $8.37 \mathrm{E}+02$ & $2.99 \mathrm{E}+02$ \\
\hline 15 Min. Avg. & $1.64 \mathrm{E}+03$ & $1.15 \mathrm{E}+02$ & $3.62 \mathrm{E}+01$ \\
\hline 30 Min. Avg. & $1.64 \mathrm{E}+03$ & $5.78 \mathrm{E}+01$ & $1.81 \mathrm{E}+01$ \\
\hline Peak Conc. & $6.80 \mathrm{E}+01$ & $3.47 \mathrm{E}+01$ & $1.24 \mathrm{E}+01$ \\
\hline 15 Min. Avg. & $6.80 \mathrm{E}+01$ & $4.79 \mathrm{E}+00$ & $1.50 \mathrm{E}+00$ \\
\hline 30 Min. Avg. & $6.80 \mathrm{E}+01$ & $2.39 \mathrm{E}+00$ & $7.51 \mathrm{E}-01$ \\
\hline Peak Conc. & $6.55 \mathrm{E}+04$ & $3.34 \mathrm{E}+04$ & $1.19 \mathrm{E}+04$ \\
\hline 15 Min. Avg. & $6.55 \mathrm{E}+04$ & $4.61 \mathrm{E}+03$ & $1.45 \mathrm{E}+03$ \\
\hline 30 Minute Average & $6.55 \mathrm{E}+04$ & $2.31 \mathrm{E}+03$ & $7.24 \mathrm{E}+02$ \\
\hline \hline
\end{tabular}

Equation 4 was used to calculate the release rate of liquefied ammonia under pressure in tanks. In this analysis, the temperature of the liquid in the tank was assumed to be ambient (27 degrees $C$ ). The vapor pressure was given in Reference [11] to be $100 \mathrm{~atm}$. Assuming a $2.54 \mathrm{~cm}$ diameter (1 inch) hole in the tank (the approximate size of a valve on such a tank), the release rate was $43.8 \mathrm{~kg} / \mathrm{s}$. At this rate, the $68 \mathrm{~kg}$ tank would be drained in less than 2 seconds, thus, no further analysis was macie on the $68 \mathrm{~kg}$ tanks since an instantaneous release could be expected. The probability of all 24 bottles 
rupturing at the same time however, seems unlikely.

Release from the $65,500 \mathrm{~kg}$ tank was evaluated for a $5.08 \mathrm{~cm}$ diameter (2 inch) hole in the tank (Abbott [16]). The release rate calculated using Equation 4 and the previously mentioned assumptions was $174.9 \mathrm{~kg} / \mathrm{s}$. The tank drain time was 6.24 minutes. The concentrations were calculated using the INPUFF code and the results (Table 3.12 ) indicate that using $95 \%$ meteorological conditions, the TLV-STEl. and IDLH limit values were exceeded in all cases. Using 50\% meteorological conditions, the TLV-STEL value was exceeded by the 15 min average concentration. However, the 30 minute average concentration was not exceeded by the IDLH value.

Table 3.12 Results of a six minute release of anhydrous ammonia from a 65,500 $\mathrm{kg}$ tank using $95 \%$ aid $50 \%$ meteorological conditions.

\begin{tabular}{||c|c|c|c|c|}
\hline \multirow{2}{*}{$\begin{array}{c}\text { Concentration } \\
\text { Type }\end{array}$} & \multicolumn{2}{|c|}{$95 \%$ Meteorology } & \multicolumn{2}{c|}{$50 \%$ Meteorology } \\
\cline { 2 - 5 } & ATR & $\star$ TRA G.S. & ATR & * TRA G.S. \\
\cline { 2 - 5 } & $\left(\mathrm{mg} / \mathrm{m}^{3}\right)$ & $\left(\mathrm{mg} / \mathrm{m}^{3}\right)$ & $\left(\mathrm{mg} / \mathrm{m}^{3}\right)$ & $\left(\mathrm{mg} / \mathrm{m}^{3}\right)$ \\
\hline Peak Conc. & $1.22 \mathrm{E}+04$ & $2.89 \mathrm{E}+03$ & $3.16 \mathrm{E}+02$ & $2.69 \mathrm{E}+02$ \\
\hline 15 Min Average & $4.84 \mathrm{E}+03$ & $1.13 \mathrm{E}+03$ & $1.24 \mathrm{E}+02$ & $1.06 \mathrm{E}+02$ \\
\hline 30 Min Average & $2.42 \mathrm{E}+03$ & $5.64 \mathrm{E}+02$ & $6.22 \mathrm{E}+01$ & $5.28 \mathrm{E}+01$ \\
\hline
\end{tabular}

* TRA Guard Station.

\subsection{Chlorine}

The chlorine inventory to be evaluated was reported to be contained in two bottles; a $68 \mathrm{~kg}(150 \mathrm{lb})$ and a $55 \mathrm{~kg}(120 \mathrm{lb})$ bottle. The total chlorine inventory was $123 \mathrm{~kg}$. The vapor pressure for chlorine was $5.075 \mathrm{E} 05 \mathrm{~Pa}$ and was obtained from Reference [11]. A $2.54 \mathrm{~cm}$ (1 inch) diameter drain valve was postulated to fail on both tanks simultaneously releasing the entire inventory of chlorine. Calculations using Equation 4 showed the tank drain times to be about 5 seconds, thus an instantaneous release was modeled as the expected case. A second set of calculations were performed for a $68 \mathrm{~kg}$ release resulting from the failure of one of the tanks. The results (Table 3.13 and 
$3.14)$ indicate the peak concentration and 15 minute average concentration exceeded the TLV-STEL $\left(3 \mathrm{mg} / \mathrm{m}^{3}\right)$ value, however, the 30 minute average concentration did not exceed the IDLH value $\left(90 \mathrm{mg} / \mathrm{m}^{3}\right)$ for the $123 \mathrm{~kg}$ release. For the $68 \mathrm{~kg}$ release, the TLV-STEL was exceeded by the peak concentration and 15 minute average concentration. The IDLH was not exceeded by the 30 minute average concentration.

The same scenarios were modeled using 50\% meteorological conditions and the calculated peak concentration never exceeded the TLV-STEL value at both the AiR and the TRA guard station for both the $123 \mathrm{~kg}$ and $68 \mathrm{~kg}$ release.

Table 3.13 Results from air dispersion modeling for a $123 \mathrm{~kg}$ instantaneous release of chlorine.

\begin{tabular}{||c|c|c|c|c|}
\hline \multirow{3}{*}{$\begin{array}{c}\text { Concentration } \\
\text { Type }\end{array}$} & \multicolumn{2}{|c|}{$95 \%$ Meteorology } & \multicolumn{2}{|c|}{$50 \%$ Meteorology } \\
\cline { 2 - 5 } & ATR & $*$ TRA G.S. & ATR & * TRA G.S. \\
\cline { 2 - 5 } & $\left(\mathrm{mg} / \mathrm{m}^{3}\right)$ & $\left(\mathrm{mg} / \mathrm{m}^{3}\right)$ & $\left(\mathrm{mg} / \mathrm{m}^{3}\right)$ & $\left(\mathrm{mg} / \mathrm{m}^{3}\right)$ \\
\hline Peak Conc. & $6.27 \mathrm{E}+01$ & $2.24 \mathrm{E}+01$ & $2.39 \mathrm{E}+00$ & $2.44 \mathrm{E}+00$ \\
\hline 15 Min Average & $8.67 \mathrm{E}+00$ & $2.71 \mathrm{E}+00$ & $9.44 \mathrm{E}-02$ & $8.41 \mathrm{E}-02$ \\
\hline 30 Min Average & $4.33 \mathrm{E}+00$ & $1.36 \mathrm{E}+00$ & $4.72 \mathrm{E}-02$ & $4.20 \mathrm{E}-02$ \\
\hline
\end{tabular}

* TRA Guard Station.

Table 3.14 Results from air dispersion modeling for a $68 \mathrm{~kg}$ instantaneous release of chlorine.

\begin{tabular}{||c|c|c|c|c||}
\hline \multirow{2}{*}{$\begin{array}{c}\text { Concentration } \\
\text { Type }\end{array}$} & \multicolumn{2}{|c|}{$95 \%$ Meteorology } & \multicolumn{2}{c|}{$50 \%$ Meteorology } \\
\cline { 2 - 5 } & ATR & $\star$ TRA G.S. & ATR & * TRA G.S. \\
\cline { 2 - 5 } & $\left(\mathrm{mg} / \mathrm{m}^{3}\right)$ & $\left(\mathrm{mg} / \mathrm{m}^{3}\right)$ & $\left(\mathrm{mg} / \mathrm{m}^{3}\right)$ & $\left(\mathrm{mg} / \mathrm{m}^{3}\right)$ \\
\hline Peak Conc. & $3.47 \mathrm{E}+01$ & $1.24 \mathrm{E}+01$ & $1.32 \mathrm{E}+00$ & $1.35 \mathrm{E}+00$ \\
\hline 15 Min Average & $4.79 \mathrm{E}+00$ & $1.50 \mathrm{E}+03$ & $5.22 \mathrm{E}-02$ & $4.65 \mathrm{E}-02$ \\
\hline 30 Min Average & $2.39 \mathrm{E}+00$ & $7.51 \mathrm{E}-01$ & $2.61 \mathrm{E}-02$ & $2.32 \mathrm{E}-02$ \\
\hline
\end{tabular}

* TRA Guard Station. 


\subsection{SUMMARY}

Hydrofluoric acid, anhydrous ammonia and chlorine were identified as chemicals which may have a potential impact at the ATR facility. These chemicals required evaluations using $50 \%$ meteorological conditions. Using $50 \%$ meteorological conditions, chlorine did exceed any of the standards. Nitric acid and ammonium hydroxide required re-evaluation using an evaporative model and the results showed minimal impact at the ATR facility and TRA guard station. The remaining chemicals were eliminated from consideration based on conservative screening calculations and thus were not considered to pose a potential threat to operation of the ATR facility. Table 4.1 shows the results of the final (least conservative) analysis for each chemical. The 15 minute average concentration was normalized to the TLV-STEL value and the 30 minute average concentration was normalized to the IDLH value. These concentrations represent the air concentration at $1 \mathrm{~m}$ height. They do not represent the air concentration inside the ATR control room facility. The air concentration inside the control room will depend on the air exchange rate, where the air intake is located and any filtration equipment on the in-coming air stream. 
Table 4.1 Simmary of the air dispersion calculations for the $1 \mathrm{~m}$ level at the ATR facility.

\begin{tabular}{|c|c|c|c|}
\hline \multirow{2}{*}{ 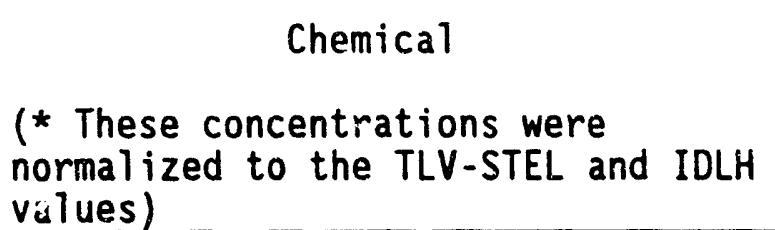 } & \multicolumn{3}{|c|}{$\begin{array}{l}\text { Air Concentration at } \\
\text { Advanced Test Reactor }\end{array}$} \\
\hline & $\begin{array}{l}\text { Peak } \\
\left(\mathrm{mg} / \mathrm{m}^{3}\right)\end{array}$ & 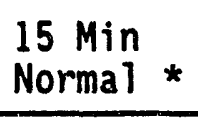 & $\begin{array}{l}30 \operatorname{Min} \\
\text { Normal * }\end{array}$ \\
\hline Ammonium Hydroxide & $2.15 E+01$ & $7.96 E-01$ & $6.14 E-02$ \\
\hline Hexone & $1.88 E+03$ & $9.70 E-01$ & $1.18 i-02$ \\
\hline Liquid Nitrogen & $1.30 E+04$ & $\ldots \ldots$ & $6.90 E-02$ \\
\hline Nitric Acid & $3.30 E+00$ & $3.30 E-01$ & $1.27 E-02$ \\
\hline Hydrofluoric Acid (ICPP Spill) & $2.50 E+00$ & $1.00 E+00$ & $1.00 \mathrm{E}-01$ \\
\hline $\begin{array}{l}\text { Hydrofluoric Acid (Road Spil1, } 50 \% \\
\text { meteorological conditions) }\end{array}$ & $3.85 E+02$ & $2.00 E+01$ & $1.01 E+01$ \\
\hline Propane & $3.10 E+03$ & $2.66 E-01$ & $6.66 E-03$ \\
\hline Gasoline & $3.42 E+03$ & $5.88 E-01$ & $1.76 E-01$ \\
\hline Anhydrous Ammonia $(1,640 \mathrm{~kg})$ & 8.37E+02 & $4.79 E+01$ & $1.65 \mathrm{E}-01$ \\
\hline $\begin{array}{l}\text { Anhydrous Ammonia }(65,500 \mathrm{~kg}, 50 \% \\
\text { meteorological conditions) }\end{array}$ & $3.16 \mathrm{E}+02$ & $5.16 E+00$ & $1.77 E-01$ \\
\hline $\begin{array}{l}\text { Chlorine ( } 50 \% \text { meteorological } \\
\text { conditions) }\end{array}$ & $1.32 E+00$ & $1.74 E-02$ & $2.90 E-04$ \\
\hline
\end{tabular}




\subsection{REFERENCES}

[1] Sulivan, C., Eide, S. A., ATR External Events Screening Analysis. EGGPRP-881, January, 1990.

[2] U.S. Atomic Energy Commission, Regulatory Guide 1.78, June 1974.

[3] ACGIH, Threshold Limit Values for Chemical Substances and Physical Agents. American Conference of Government Industrial Hygienists, 1990.

[4] NIOSH Pocket Guide to Chemical Hazards, U.S. Department of Health and Human Services/U.S. Department of Labor Publication No. 78-210, 1985.

[5] Tozer, J. C., Parameters for ATR Chemical Release Analysis. EGG Letter File Number JCT-01-91, January 14, 1991.

[6] Petersen, W.B., L.G. Lavdas, 1988. INPUFF 2.0 - A Multiple Source Gaussian Puff Dispersion Algorithm. U.S. EPA, Research Triangle Park.

[7] Kunke1, B. A., User's Guide for the Air Force Toxic Chemical Dispersion Model (AFTOX). Air Force Geophysical Laboratory, Hanscom AFB AFGL-TR-88-0009, 1988.

[8] Start, G. E. Letter to Les Finch of WINCO, March 24, 1989. Interim Guidance for Dispersion Calculations at ICPP.

[9] Special Isotope Separation Facility, Safety Analysis Report 1989

[10] Fleisher, M.T., SPILLS An Evaporative/Air Dispersion Model for Chemical Spills on Land. Shell Development Company, 1980.

[11] Ontario Ministry of the Environment, Portable Computing System for Use in Toxic Gas Emergencies. Report Number ARB-162-83-ARSP, 1983.

[12] Risk Analysis of Six Potentially Hazardous Industrial Objects in the Rijnmond Area; A Pilot Study, Appendix III. D. Reidel Publishing Company, Dordrecht, Hol and, 1982.

[13] Perry, R. H. and C.H. Chilton, Chemicals Engineers' Handbook. McGraw Hi11 Book Company, New York, 1973.

[14] Meyer, E., Chemistry of Hazardous Materials. Prentice Hall New Jersey, 1989.

[15] Hawley, G. G., The Condensed Chemical Dictionary. Van Nostrand Reinhold Company, New York, 1971.

[16] Abbott, M.L., Hydrofluoric Acid and Anhydrous Ammonia Spills Evaporation/Air Dispersion Modeling and Exposure Assessment. EGG-EST-8946, 1990. 
APPENDIX A - CALCULATION OF 95\% AND 50\% METEOROLOGICAL CONDITIONS FROM A JOINT FREQUENCY DISTRIBUTION

$A-1$ 


\section{APPENDIX A}

\section{CALCULATION OF 95\% AND 50\% METEOROLOGICAL CONDITIONS \\ FROM A JOINT FREQUENCY DISTRIBUTION}

The 95\% meteorological conditions are defined as the meteorological conditions, which, for a given release, the concentration at a fixed receptor location will not be exceeded $95 \%$ of the time. The $50 \%$ meteorological conditions are defined as the meteorological conditions, which, for a given release, the concentration at a fixed receptor location will not be exceeded $50 \%$ of the time. The $95 \%$ and $50 \%$ meteorological conditions were calculated for the SE sector of the Grid III meteorological station. The fraction of the time the wind blew in the SE sector was assumed to be 1.0. The fraction of time the wind blew for a given stability class and wind speed class in the SE sector was factored into the calculation. In addition, the calm hours were also proportioned into the lowest wind speed class. 


\section{A-1 BASIC METHODOLOGY AND DATA}

The joint frequency distribution (JFD) data is as follows

Location: GRID III

Height of Measurements: $10 \mathrm{~m}$

Time Span of Data Collection: 1982 - 1986

Sector of Interest (sector wind blew from): SE

These $50 \%$ and $95 \% \mathrm{CHI} / Q$ values are applicable to receptors which are located in the $\mathrm{NW}$ sector relative to the source. The data was partitioned into six stability categories $(A-F)$ and seven wind speed classes. The maximum and mean wind speeds for the seven classes are listed in Table A-1.

Table A-1 Wind speed classes used in $95 \%$ and $50 \%$ met. calculations.

\begin{tabular}{lcc}
\hline $\begin{array}{c}\text { Wind Speed } \\
\text { Class }\end{array}$ & $\begin{array}{c}\text { Maximum } \\
\text { Wind Speed } \\
(\mathrm{m} / \mathrm{s})\end{array}$ & $\begin{array}{c}\text { Mean } \\
\text { Wind Speed } \\
(\mathrm{m} / \mathrm{s})\end{array}$ \\
\hline 1 & 1.57 & 0.84 \\
2 & 3.35 & 2.49 \\
3 & 5.59 & 4.47 \\
4 & 8.27 & 6.93 \\
5 & 10.95 & 9.61 \\
6 & 15.42 & 13.19 \\
7 & 22.58 & 19.00 \\
\hline
\end{tabular}

The calm hours were proportioned into the lowest wind speed class for each stability category based on the fraction of hours the wind blew in the lowest wind speed class for a particular sector. For example, in the SE sector, stability class $A$, the wind blew 13 hours for the period in the lowest wind speed class. The total number of hours the wind blew in the lowest wind speed class for stability class $A$ was 195 hours. The number of calm hours reported in stability class $A$ for the measurement period was 77 hours. The fraction of calm hours to be added to stability class A, SE sector, lowest wind speed class was 
195 hours

These data are presented in Table A-2 and A-3.

The proportioned calm hours were added to the lowest wind speed class of each stability category. The $\mathrm{CHI} / \mathrm{Q}$ (concentration/release rate) values were calculated for a steady state release where the effective stack height was 1.0 $m$ and the receptor was along the plume centerline at ground level. The equation used to calculate the $\mathrm{CHI} / Q$ values was (Moore et al., 1979).

$$
\frac{\mathrm{X}}{Q}=\frac{1}{\pi \sigma_{y} \sigma_{x} u} \exp \left(-0.5\left(\frac{H}{\sigma_{x}}\right)^{2}\right)
$$

where

$1 / Q=$ concentration $/$ release rate $\left(\mathrm{s} / \mathrm{m}^{3}\right)$

$\sigma_{y}, \sigma_{z}=$ plume standard deviations in the $y$ and $z$ directions ( $m$ )

$H=$ effective stack height $(m)$

$u=$ mean wind speed $(\mathrm{m} / \mathrm{s})$

The $\sigma_{y}, \sigma_{z}$ and $\sigma_{x}$ values were estimated using the expressions in Table A-4. 
Table A-2 Number of hours wind blew in first wind speed class in each of the 16 sectors for each stability class.

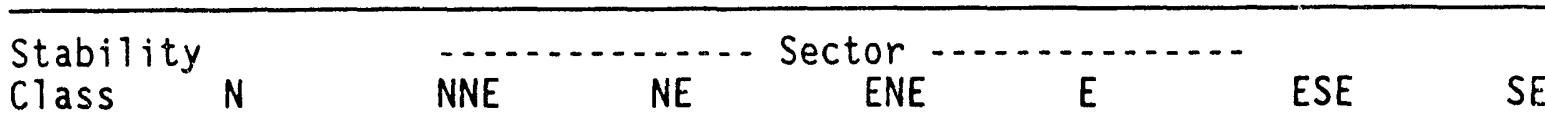
A $\quad 1.000 E+01 \quad 1.100 E+01 \quad 9.000 E+00 \quad 9.000 E+00 \quad 1.500 E+01 \quad 7.000 E+00 \quad 1.300 E+01$
B $\quad 4.300 E+01 \quad 8.500 E+01 \quad 1.150 E+02 \quad 7.10 C E+01 \quad 4.000 E+01 \quad 5.300 E+01 \quad 3.800 E+01$
C $\quad 1.280 E+02 \quad 1.980 E+02 \quad 2.110 E+02 \quad 9.800 E+01 \quad 4.200 E+01 \quad 6.500 E+01 \quad 6.000 E+01$
D $\quad 1.100 E+01 \quad 1.600 E+01 \quad 1.500 E+01 \quad 8.000 E+00 \quad 3.000 E+00 \quad 4.000 E+00 \quad 0.000 E+00$
$\begin{array}{llllllllll}1 & 8.500 E+01 & 6.900 E+01 & 4.700 E+01 & 2.000 E+01 & 2.700 E+01 & 2.300 E+01 & 2.200 E+01\end{array}$
$F \quad 4.440 E+02 \quad 4.160 E+02 \quad 3.330 E+02 \quad 1.550 E+02 \quad 9.200 E+01 \quad 8.800 E+01 \quad 1.160 E+02$

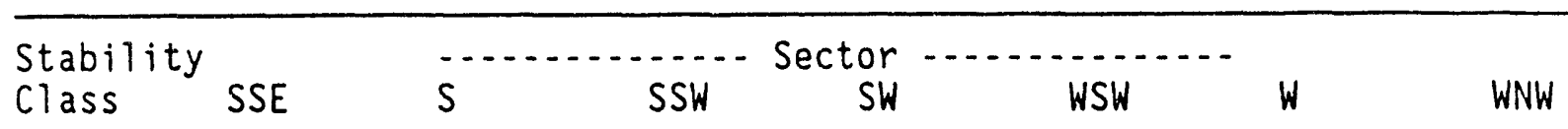
A $\quad 1.400 E+01 \quad 4.600 E+01 \quad 2.000 E+01 \quad 1.800 E+01 \quad 1.100 E+012.000 E+00 \quad 2.000 E+00$
B $\quad 4.900 E+01 \quad 1.060 E+02 \quad 7.600 E+01 \quad 5.400 E+01 \quad 3.200 E+01 \quad 2.300 E+01 \quad 1.700 E+01$
$\begin{array}{lllllllll}C & 6.000 E+01 & 1.590 E+02 & 1.340 E+02 & 1.440 E+02 & 1.170 E+02 & 6.300 E+01 & 4.800 E+01\end{array}$
D $\quad 5.000 E+00 \quad 8.000 E+00 \quad 1.100 E+019.000 E+00 \quad 9.000 E+00 \quad 4.000 E+00 \quad 4.000 E+00$
E $\quad 4.200 E+01 \quad 5.500 E+01 \quad 5.500 E+01 \quad 8.900 E+01 \quad 6.300 E+01 \quad 3.900 E+013.000 E+01$

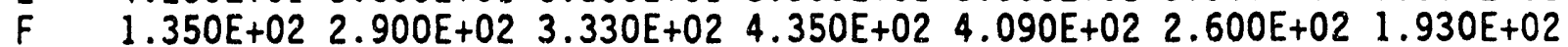

$\begin{array}{lcccr} & N W & N N W & \text { TOTAL } & \text { CALM HOURS } \\ A & 4.000 E+00 & 4.000 E+00 & 1.950 E+02 & 7.700 E+01 \\ B & 2.000 E+01 & 2.700 E+01 & 8.490 E+02 & 4.460 E+02 \\ C & 3.000 E+01 & 5.000 E+01 & 1.607 E+03 & 9.190 E+02 \\ D & 0.000 E+00 & 3.000 E+00 & 1.100 E+02 & 3.800 E+01 \\ E & 3.900 E+01 & 4.300 E+01 & 7.480 E+02 & 1.690 E+02 \\ F & 1.930 E+02 & 2.740 E+02 & 4.166 E+03 & 2.315 E+03\end{array}$

Table A-3 Number of calm hours added to the first wind speed class in each of the 16 sectors for each stability class.

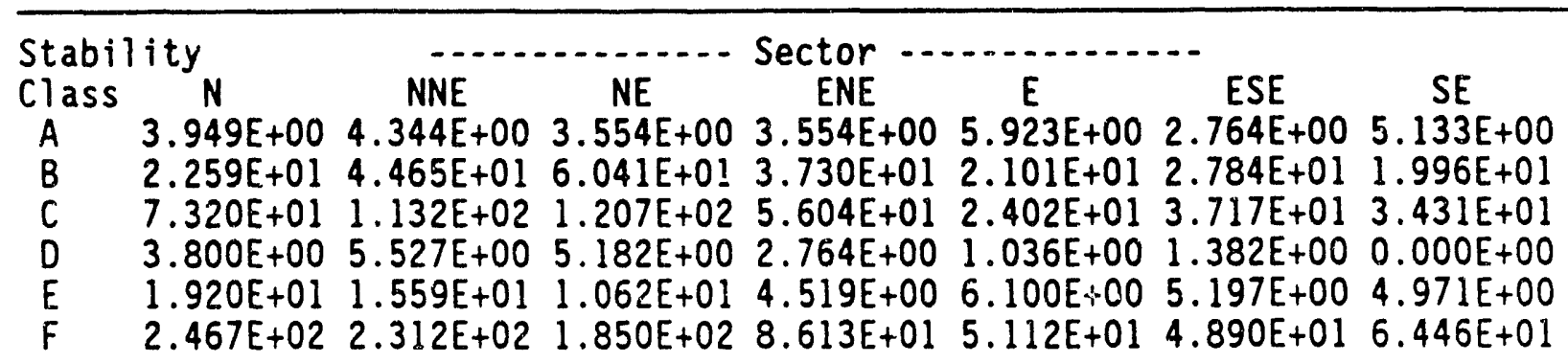




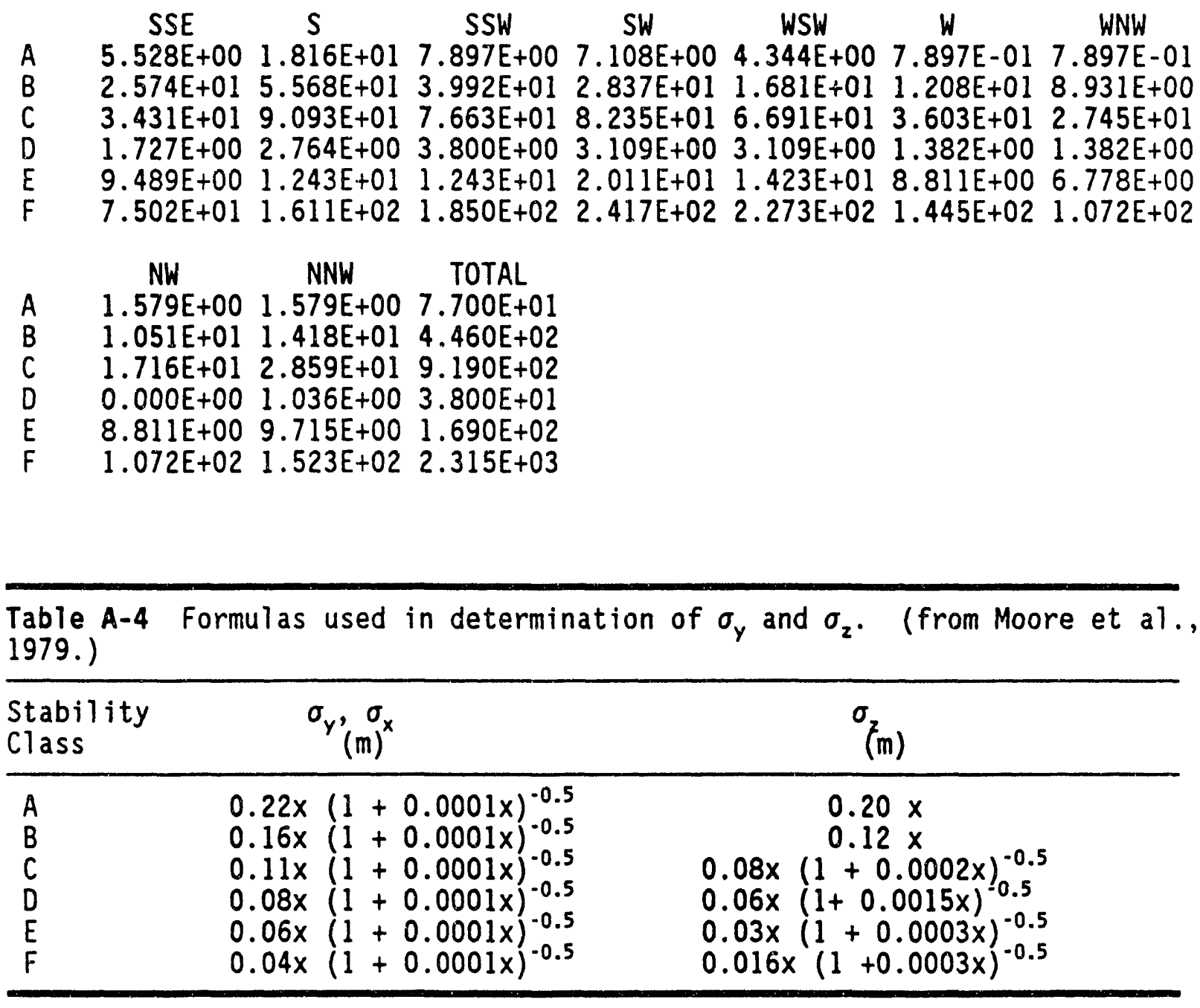

\section{A-2 $50 \%$ AND $95 \%$ CHI/O VALUES FOR THE SE SECTOR.}

Results of the calculation of $\mathrm{CHI} / \mathrm{Q}$ for all wind speeds and stability classes are presented in Table A-5. In addition, number of hours and the fraction of time the wind persisted at these conditions was also presented. The $\mathrm{CHI} / \mathrm{Q}$ values for a particular wind speed and stability class were multiplied by the fraction of time those meteorological conditions persisted while the wind blew in the SE sector giving a "Time Weighted " CHI/Q (TWCQ). (This analysis doesn't consider the probability that the wind blows in a particular sector) The "Time Weighted" CHI/Q (TWCQ) was then sorted in ascending order. A fractional value was attached to each TWCQ which represents the fraction of the TWCQ's which were less than the particular TWCQ value. The fractional 
value was given by

$$
f=\frac{p}{n}
$$

where $P=$ the rank position of the $\mathrm{CHI} / Q$ ( 1 to $n$ )

$n=$ the number of $\mathrm{CHI} / \mathrm{Q}$ values.

The 50\% TWCQ (50\% of the TWCQ values are less than this value) for the SE sector was $2.36 E-09 \mathrm{~s} / \mathrm{m}^{3}$. This TWCQ was calculated using stability $D$ and $13.9 \mathrm{~m} / \mathrm{s}$ wind speed. The $95 \%$ TWCQ was $1.58 E-06 \mathrm{~s} / \mathrm{m}^{3}$ and was calculated using stability class $E$ and $0.84 \mathrm{~m} / \mathrm{s}$ wind speed (Table 6 ). 
Table A-5 CHI/Q values and fraction of time the wind blew at a particular stability class and wind speed for the SE sector of the $10 \mathrm{~m}$ level Grid III meteorological station.

\begin{tabular}{lllllll}
\hline STABILITY & MEAN WIND NUMBER OF & FRACTION & $\sigma_{\mathrm{Y}}$ & $\sigma_{2}$ & $\mathrm{CHI} / \mathrm{Q}$ \\
CLASS & SPEED & HOURS & OF TIME & $(\mathrm{m})$ & $(\mathrm{m})$ & \\
& $(\mathrm{m} / \mathrm{s})$ & & & & &
\end{tabular}

A

A

A

A

A

A

A

B

B

B

B

B

B

B

C

C

c

C

C

C

C

D

D

D

D

D

\section{D}

D

\section{E}

E

E

E

E

F

$F$

$F$

F

F

$F$

8.350E-01 $1.813 E+01 \quad 2.727 E-02 \quad 5.617 E+02 \quad 5.800 E+02 \quad 1.171 E-06$ $2.490 \mathrm{E}+00 \quad 7.000 \mathrm{E}+00 \quad 1.053 \mathrm{E}-02 \quad 5.617 \mathrm{E}+02 \quad 5.800 \mathrm{E}+02 \quad 3.926 \mathrm{E}-07$

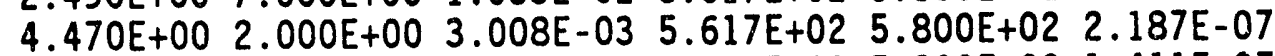

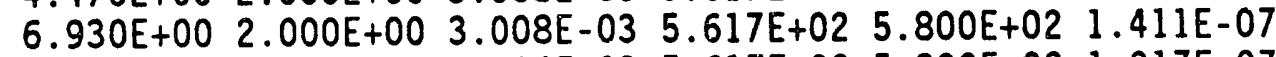
$9.610 \mathrm{E}+001.000 \mathrm{E}+00 \quad 1.504 \mathrm{E}-03 \quad 5.617 \mathrm{E}+02 \quad 5.800 \mathrm{E}+02 \quad 1.017 \mathrm{E}-07$

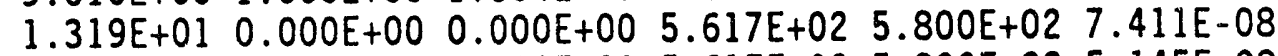

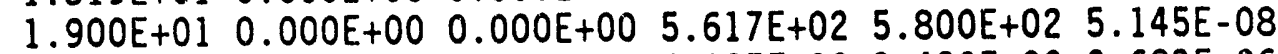

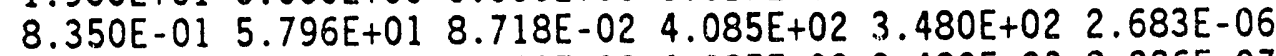
$2.490 \mathrm{E}+00 \quad 2.600 \mathrm{E}+01 \quad 3.911 \mathrm{E}-02 \quad 4.085 \mathrm{E}+02 \quad 3.480 \mathrm{E}+02 \quad 8.996 \mathrm{E}-07$

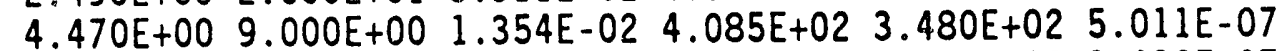

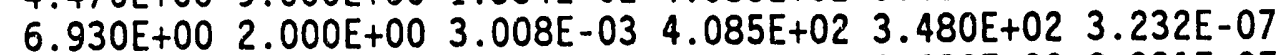
$9.610 \mathrm{E}+00 \quad 0.000 \mathrm{E}+00 \quad 0.000 \mathrm{E}+00 \quad 4.085 \mathrm{E}+02 \quad 3.480 \mathrm{E}+02 \quad 2.331 \mathrm{E}-07$

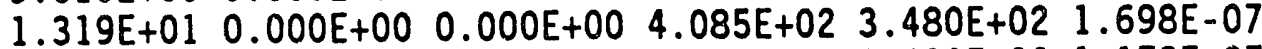

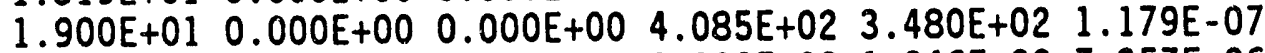

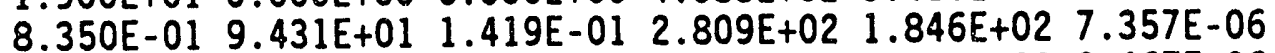
$2.490 \mathrm{E}+00 \quad 4.300 \mathrm{E}+01 \quad 6.468 \mathrm{E}-02 \quad 2.809 \mathrm{E}+02 \quad 1.846 \mathrm{E}+02 \quad 2.467 \mathrm{E}-06$

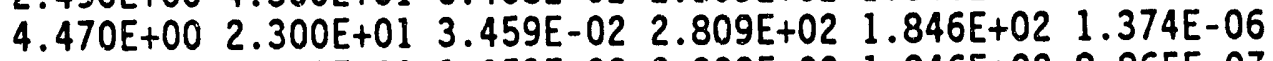
$6.930 \mathrm{E}+00 \quad 7.000 \mathrm{E}+00 \quad 1.053 \mathrm{E}-02 \quad 2.809 \mathrm{E}+02 \quad 1.846 \mathrm{E}+02 \quad 8.865 \mathrm{E}-07$

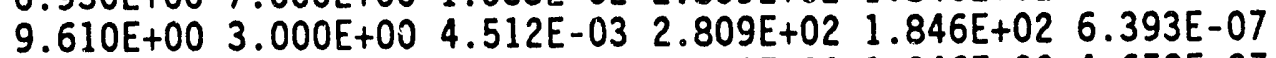
$\begin{array}{llllll}1.319 E+01 & 0.000 E+00 & 0.000 E+00 & 2.809 E+02 & 1.846 E+02 & 4.658 E-07\end{array}$

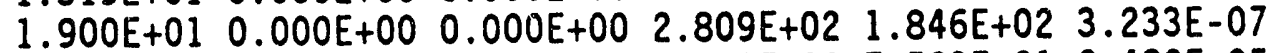
$\begin{array}{lllllll}8.350 E-01 & 0.000 E+00 & 0.000 E+00 & 2.043 E+02 & 7.523 E+01 & 2.482 E-05\end{array}$ $2.490 \mathrm{E}+00 \quad 6.000 \mathrm{E}+00 \quad 9.025 \mathrm{E}-03 \quad 2.043 \mathrm{E}+02 \quad 7.523 \mathrm{E}+01 \quad 8.323 \mathrm{E}-06$

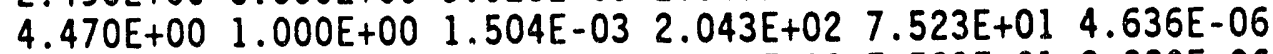
$6.930 E+00 \quad 1.000 E+00 \quad 1.504 E-03 \quad 2.043 E+02 \quad 7.523 E+01 \quad 2.990 E-06$ $9.610 E+00 \quad 0.000 E+00 \quad 0.000 E+00 \quad 2.043 E+02 \quad 7.523 E+012.156 E-06$

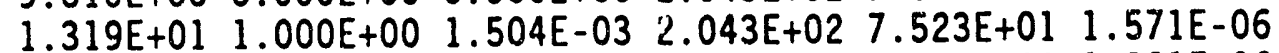

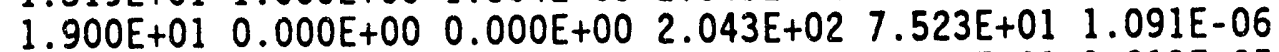
8.350E-01 2.697E+01 4.057E-02 $1.532 E+02 \quad 6.362 E+01 \quad 3.913 E-05$ $2.490 E+00 \quad 3.000 E+01 \quad 4.512 E-02 \quad 1.532 E+02 \quad 6.362 E+01 \quad 1.312 E-05$ $\begin{array}{llllll}4.470 E+00 & 7.000 E+00 & 1.053 E-02 & 1.532 E+02 & 6.362 E+01 & 7.309 E-06\end{array}$ $\begin{array}{llllll}6.930 E+00 & 0.000 E+00 & 0.000 E+00 & 1.532 E+02 & 6.362 E+01 & 4.714 E-06\end{array}$ $\begin{array}{llllll}9.610 E+00 & 0.000 E+00 & 0.000 E+00 & 1.532 E+02 & 6.362 E+01 & 3.400 E-06\end{array}$ $\begin{array}{lllllll}1.319 E+01 & 0.000 E+00 & 0.000 E+00 & 1.532 E+02 & 6.362 E+01 & 2.477 E-06\end{array}$

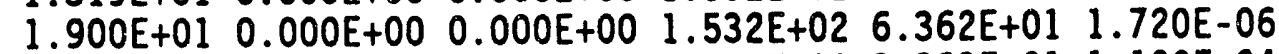
8.350E-01 $1.805 E+02 \quad 2.714 E-01 \quad 1.021 E+02 \quad 3.393 E+01 \quad 1.100 E-04$ $\begin{array}{llllll}2.490 E+00 & 9.200 E+01 & 1.384 E-01 & 1.021 E+02 & 3.393 E+01 & 3.689 E-05\end{array}$ $\begin{array}{llllll}4.470 E+00 & 1.700 E+01 & 2.557 E-02 & 1.021 E+02 & 3.393 E+01 & 2.055 E-05\end{array}$

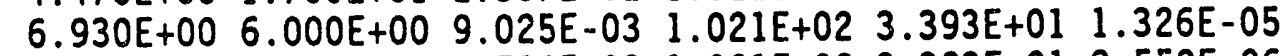
$9.610 \mathrm{E}+00 \quad 1.000 \mathrm{E}+00 \quad 1.504 \mathrm{E}-03 \quad 1.021 \mathrm{E}+02 \quad 3.393 \mathrm{E}+01 \quad 9.559 \mathrm{E}-06$

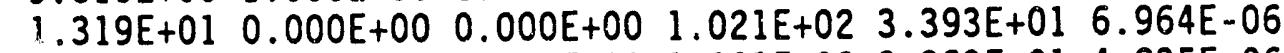

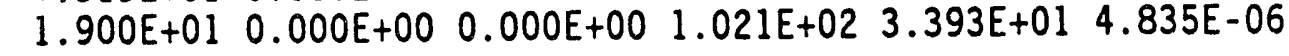


Table A-5 Time weighted $\mathrm{CHI} / Q$ values fraction of $\mathrm{CHI} / Q$ values less than the given value for the SE sector of GRID III.

\begin{tabular}{|c|c|c|c|c|c|}
\hline $\begin{array}{c}\text { Stability } \\
\text { Class }\end{array}$ & $\begin{array}{l}\text { Wind } \\
\text { Speed } \\
(\mathrm{m} / \mathrm{s})\end{array}$ & $\begin{array}{l}\mathrm{CHI} / \mathrm{Q} \\
\left(\mathrm{s} / \mathrm{m}^{3}\right)\end{array}$ & $\begin{array}{l}\text { Fraction } \\
\text { of Time }\end{array}$ & $\begin{array}{c}\text { Time } W t \\
\mathrm{CHI} / \mathrm{Q} \\
\left(\mathrm{s} / \mathrm{m}^{3}\right)\end{array}$ & $\begin{array}{l}\text { Fraction of } \mathrm{CHI} / \mathrm{Q} \\
\text { Values Less Than }\end{array}$ \\
\hline $\begin{array}{l}D \\
D \\
D \\
B \\
C \\
C \\
E \\
F \\
F \\
E \\
E \\
E \\
B \\
A \\
A \\
B \\
A \\
A \\
A \\
B \\
D \\
C \\
A \\
D \\
B \\
D \\
C \\
F \\
A \\
B \\
C \\
D \\
E \\
F \\
C \\
B \\
F \\
E \\
C \\
E \\
F \\
F\end{array}$ & $\begin{array}{l}0.84 \\
9.61 \\
19.00 \\
19.00 \\
13.19 \\
19.00 \\
19.00 \\
13.19 \\
19.00 \\
6.93 \\
9.61 \\
13.19 \\
13.19 \\
19.00 \\
13.19 \\
9.61 \\
9.61 \\
6.93 \\
4.47 \\
6.93 \\
13.19 \\
9.61 \\
2.49 \\
6.93 \\
4.47 \\
4.47 \\
6.93 \\
9.61 \\
0.84 \\
2.49 \\
4.47 \\
2.49 \\
4.47 \\
6.93 \\
2.49 \\
0.84 \\
4.47 \\
2.49 \\
0.84 \\
0.84 \\
2.49 \\
0.84\end{array}$ & 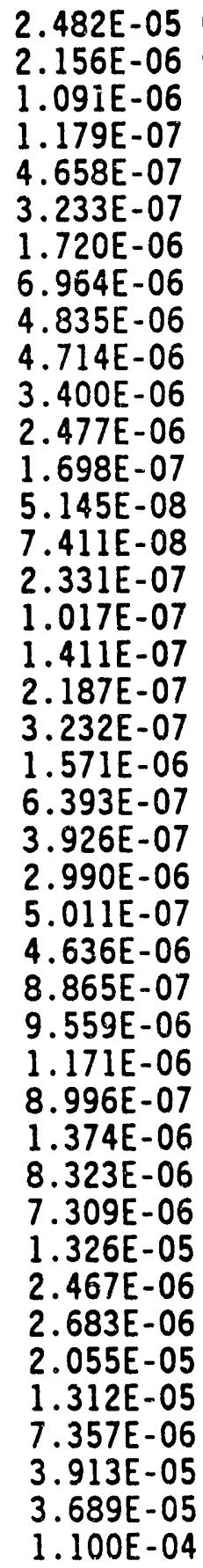 & $\begin{array}{l}0.000 E+00 \\
0.000 E+00 \\
0.000 E+00 \\
0.000 E+00 \\
0.000 E+00 \\
0.000 E+00 \\
0.000 E+00 \\
0.000 E+00 \\
0.000 E+00 \\
0.000 E+00 \\
0.000 E+00 \\
0.000 E+00 \\
0.000 E+00 \\
0.000 E+00 \\
0.000 E+00 \\
0.000 E+00 \\
1.504 E-03 \\
3.008 E-03 \\
3.008 E-03 \\
3.008 E-03 \\
1.504 E-03 \\
4.512 E-03 \\
1.053 E-02 \\
1.504 E-03 \\
1.354 E-02 \\
1.504 E-03 \\
1.053 E-02 \\
1.504 E-03 \\
2.727 E-02 \\
3.911 E-02 \\
3.459 E-02 \\
3.025 E-03 \\
1.053 E-02 \\
9.025 E-03 \\
6.468 E-02 \\
8.718 E-02 \\
2.557 E-02 \\
4.512 E-02 \\
1.419 E-01 \\
4.057 E-02 \\
1.384 E-01 \\
2.714 E-01\end{array}$ & $\begin{array}{l}0.000 E+00 \\
0.000 E+00 \\
0.000 E+00 \\
0.000 E+00 \\
0.000 E+00 \\
0.000 E+00 \\
0.000 E+00 \\
0.000 E+00 \\
0.000 E+00 \\
0.000 E+00 \\
0.000 E+00 \\
0.000 E+00 \\
0.000 E+00 \\
0.000 E+00 \\
0.000 E+00 \\
0.000 E+00 \\
1.530 E-10 \\
4.243 E-10 \\
6.578 E-10 \\
9.724 E-10 \\
2.363 E-09 \\
2.885 E-09 \\
4.133 E-09 \\
4.498 E-09 \\
6.784 E-09 \\
6.973 E-09 \\
9.334 E-09 \\
1.438 E-08 \\
3.193 E-08 \\
3.518 E-08 \\
4.755 E-08 \\
7.511 E-08 \\
7.696 E-08 \\
1.196 E-07 \\
1.596 E-07 \\
2.339 E-07 \\
5.255 E-07 \\
5.921 E-07 \\
1.044 E-06 \\
1.587 E-06 \\
5.105 E-06 \\
2.986 E-05\end{array}$ & 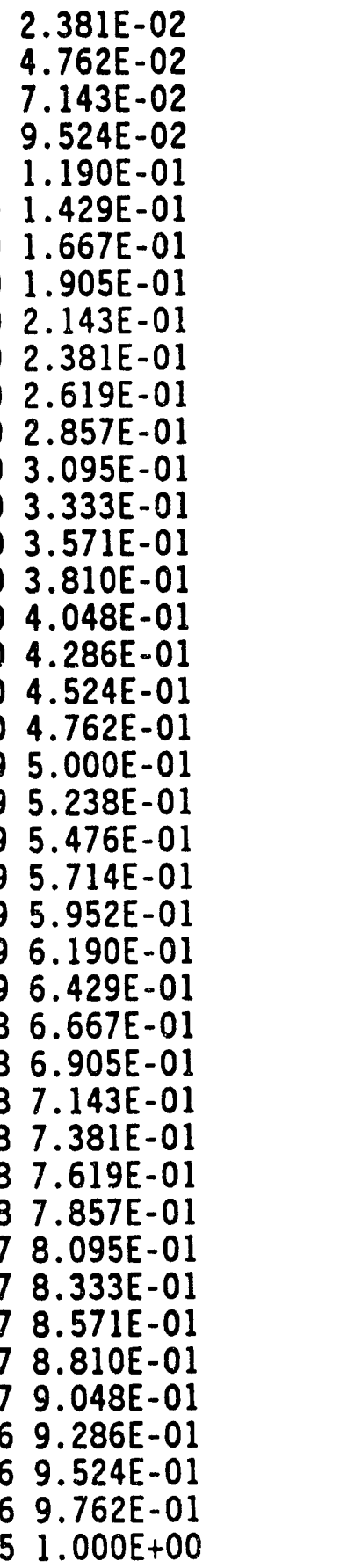 \\
\hline
\end{tabular}




\section{Reference:}

Moore, R.E., Baes, C.F., McDowel1-Boyer, L.M., Watson, A.P., Hoffman, F.0., Pleasane, J.C., Miller, C.W., AIRDOS-EPA: A Computerized Methodology for Estimating Environmental Concentrations and Dose to Man From Airborne Releases of Radionuclides. ORNL-5532, 1979. 

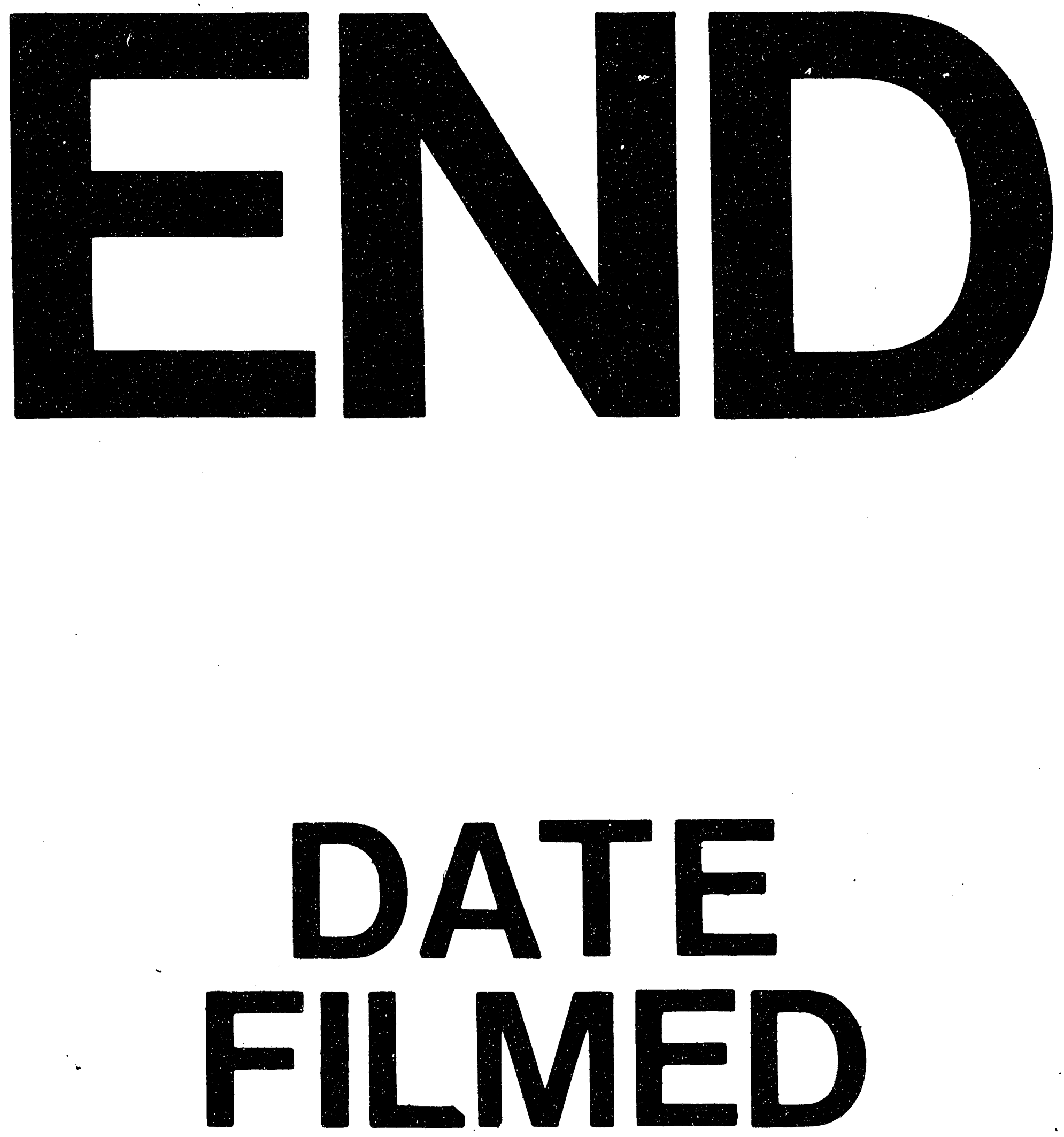

I

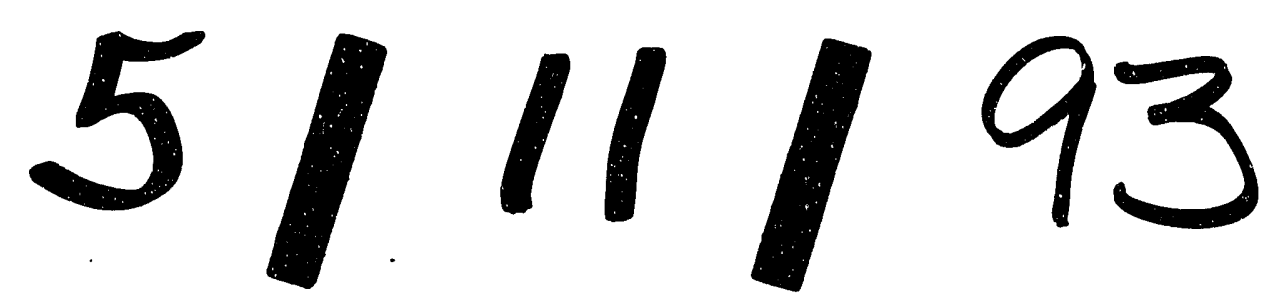


